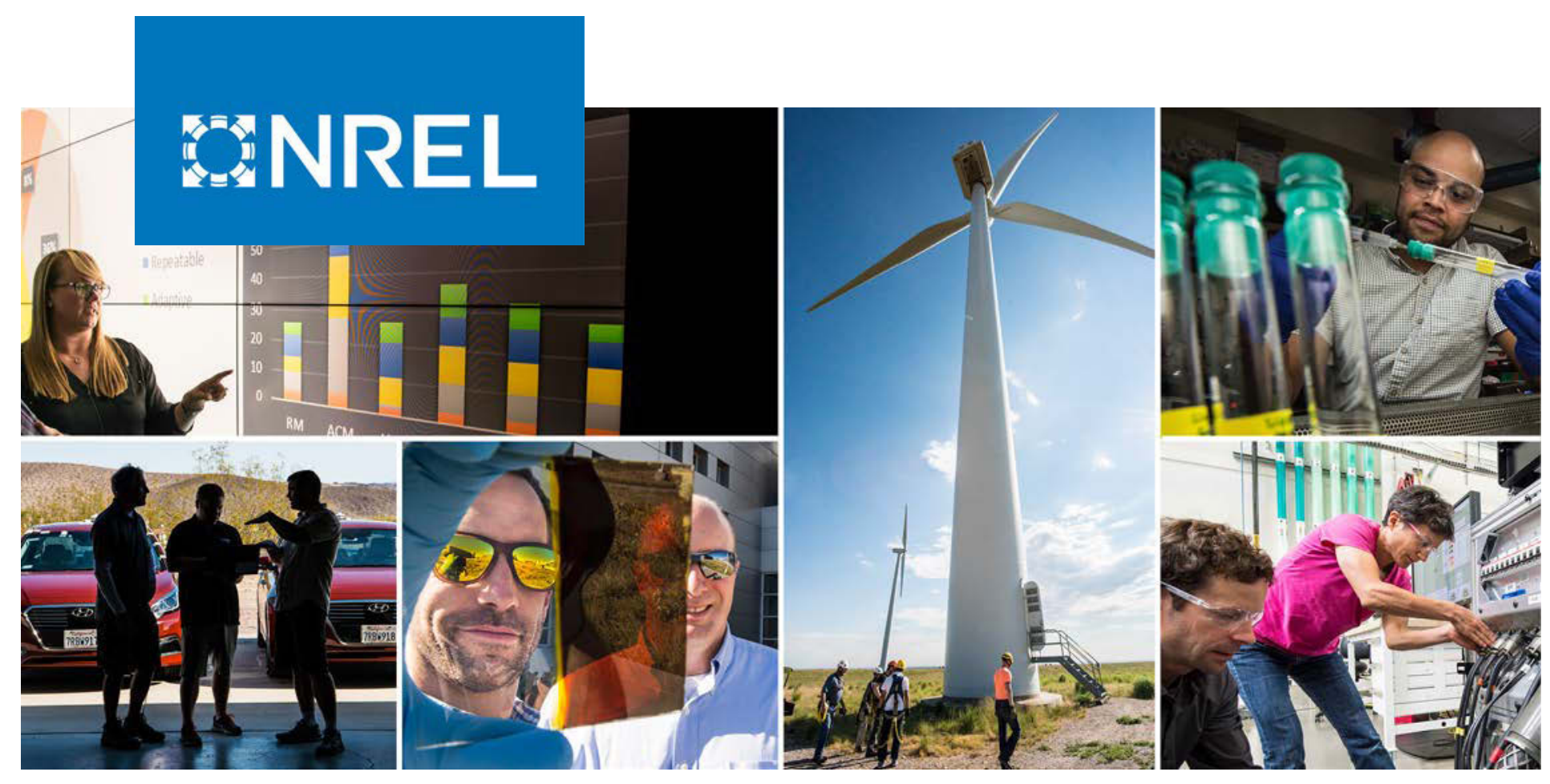

\title{
End-of-Life Evaluation of Compressed Natural Gas Vehicle Fuel Tanks
}

Aaron Williams and Lauren A. Lynch

National Renewable Energy Laboratory

NREL is a national laboratory of the U.S. Department of Energy

Office of Energy Efficiency \& Renewable Energy

Operated by the Alliance for Sustainable Energy, LLC

This report is available at no cost from the National Renewable Energy Laboratory (NREL) at www.nrel.gov/publications.
Technical Report

NREL/TP-5400-80446

July 2021 


\title{
GHREL
}

\section{End-of-Life Evaluation of Compressed Natural Gas Vehicle Fuel Tanks}

\author{
Aaron Williams and Lauren A. Lynch \\ National Renewable Energy Laboratory
}

\section{Suggested Citation}

Williams, Aaron and Lauren A. Lynch. 2021. End-of-Life Evaluation of Compressed Natural Gas Vehicle Fuel Tanks. Golden, CO: National Renewable Energy Laboratory. NREL/TP-5400-80446. https://www.nrel.gov/docs/fy21osti/80446.pdf.

NREL is a national laboratory of the U.S. Department of Energy Office of Energy Efficiency \& Renewable Energy Operated by the Alliance for Sustainable Energy, LLC

This report is available at no cost from the National Renewable Energy Laboratory (NREL) at www.nrel.gov/publications.

Contract No. DE-AC36-08GO28308
Technical Report NREL/TP-5400-80446 July 2021

National Renewable Energy Laboratory 15013 Denver West Parkway Golden, CO 80401 303-275-3000 • www.nrel.gov 


\section{NOTICE}

This work was authored by the National Renewable Energy Laboratory, operated by Alliance for Sustainable Energy, LLC, for the U.S. Department of Energy (DOE) under Contract No. DE-AC3608GO28308. Funding provided by the U.S. Department of Energy Office of Energy Efficiency and Renewable Energy's Vehicle Technologies Office. The views expressed herein do not necessarily represent the views of the DOE or the U.S. Government.

This report is available at no cost from the National

Renewable Energy Laboratory (NREL) at

www.nrel.gov/publications.

U.S. Department of Energy (DOE) reports produced

after 1991 and a growing number of pre-1991

documents are available

free via www.OSTI.gov.

Cover Photos by Dennis Schroeder: (clockwise, left to right) NREL 51934, NREL 45897, NREL 42160, NREL 45891, NREL 48097, NREL 46526.

NREL prints on paper that contains recycled content. 


\section{Acknowledgments}

The authors would like to thank the Los Angeles County Metropolitan Transportation Authority for their donation of compressed natural gas fuel tanks, as well as attendees to the Natural Gas Vehicle Technology Forum and all other subject matter experts who contributed input and feedback for their collaboration and information provided in support of this study. The authors would also like to thank John Gonzales, Kay Kelly, Brian Burks, Margo Melendez, and Dennis Smith for their contributions and input, as well as Michael Deneen for his diligence and attention to detail while editing this report. 


\section{List of Acronyms}

ANSI American National Standards Institute

CGA Compressed Gas Association

CNG compressed natural gas

CSA CSA Group

EOL end of life

FMVSS Federal Motor Vehicle Safety Standards

$\mathrm{Hz} \quad$ hertz

ISO International Organization for Standardization

LA Los Angeles

MAE modal acoustic emission

$\mathrm{NGV}$ natural gas vehicle

NGV2 CSA/ANSI NGV 2-2019 standard

NREL National Renewable Energy Laboratory

PHMSA Pipeline and Hazardous Materials Safety Administration

psig pounds per square inch gauge 


\section{Executive Summary}

The end-of-life (EOL) requirement of compressed natural gas (CNG) fuel tanks can vary from the variable service life of the vehicle, compelling the vehicle owner to replace the fuel tank in compliance with the tank manufacturer's EOL requirements. CNG fuel tanks that need to be replaced before the end of the vehicle's service life are a financial burden to the vehicle owner and increases acute hazards related to the removal and reinstallation of the tanks, such as improper fitment of replacement fuel tanks, brackets, and mounting components. Federal Motor Vehicle Safety Standards (FMVSS) No. 304 requires a visual inspection of CNG fuel tanks (eCFR 2020), avoiding unnecessary removal and reinstallation of tanks to prevent such hazards. Removal and replacement of expired CNG fuel tanks also introduces concerns of resale of expired tanks or incorrect disposal of CNG fuel tanks.

There are no FMVSS that define the EOL requirement for CNG fuel tanks as they are defined by the manufacturer, and there are limited and inconsistent enforcement efforts to ensure vehicle owners adhere to the EOL requirements for CNG fuel tanks. Therefore, it is not uncommon for CNG vehicles to continue utilizing CNG fuel tanks that have surpassed their defined EOL requirements.

The U.S. Department of Energy undertook this project to investigate the structural integrity of CNG fuel tanks under routine operating conditions at the end of their defined useful life. This information would allow the industry to better identify, understand, and mitigate safety risks and address barriers and opportunities related to $\mathrm{CNG}$ storage onboard vehicles.

This study evaluated the structural integrity of Type III and Type IV CNG fuel tanks from the Los Angeles (LA) County Metropolitan Transportation Authority to characterize the fuel tank conditions after experiencing a full service life of 15 years in transit bus application. The data produced provide insight about the condition of the CNG fuel tanks at the conclusion of their defined EOL and potential risks of continued operation of the CNG vehicle without replacement of the expired fuel tanks. In addition to physical testing performed on the fuel tanks, a nondestructive evaluation of modal acoustic emission (MAE) was utilized to assess the structural integrity of the tanks. The CNG fuel tanks were evaluated in their received condition and after experiencing artificial damage. The MAE results were then compared to visual inspection results of the procedures defined in the Compressed Gas Association's (CGA's) C-6.2 and C-6.4 standards (Compressed Gas Association 2013; 2012) to better understand the effectiveness of the visual inspection and potential safety risks of continued use of the tanks.

A total sample size of $60 \mathrm{CNG}$ fuel tanks were tested to characterize the structural integrity at their defined EOL of 15 years in comparison to the CSA Group/American National Standards Institute's (CSA/ANSI's) design and performance standard, CSA/ANSI NGV 2-2019 (NGV2) (CSA/ANSI 2019). Twenty of the 60 tanks were burst-tested without being subjected to any additional damage to establish a baseline understanding of the tank's structural integrity at EOL. An additional 20 tanks were subjected to artificial notch and impact damage followed by fatigue cycling and burst pressure testing to understand structural durability. Another 20 tanks were subjected to hydraulic fatigue cycling followed by a burst test to simulate continued use of the tanks beyond their defined EOL. Two of these 20 tanks were also leak-tested to understand 
potential for additional failure modes. An outline summary of the CNG fuel tanks tested and their results follows:

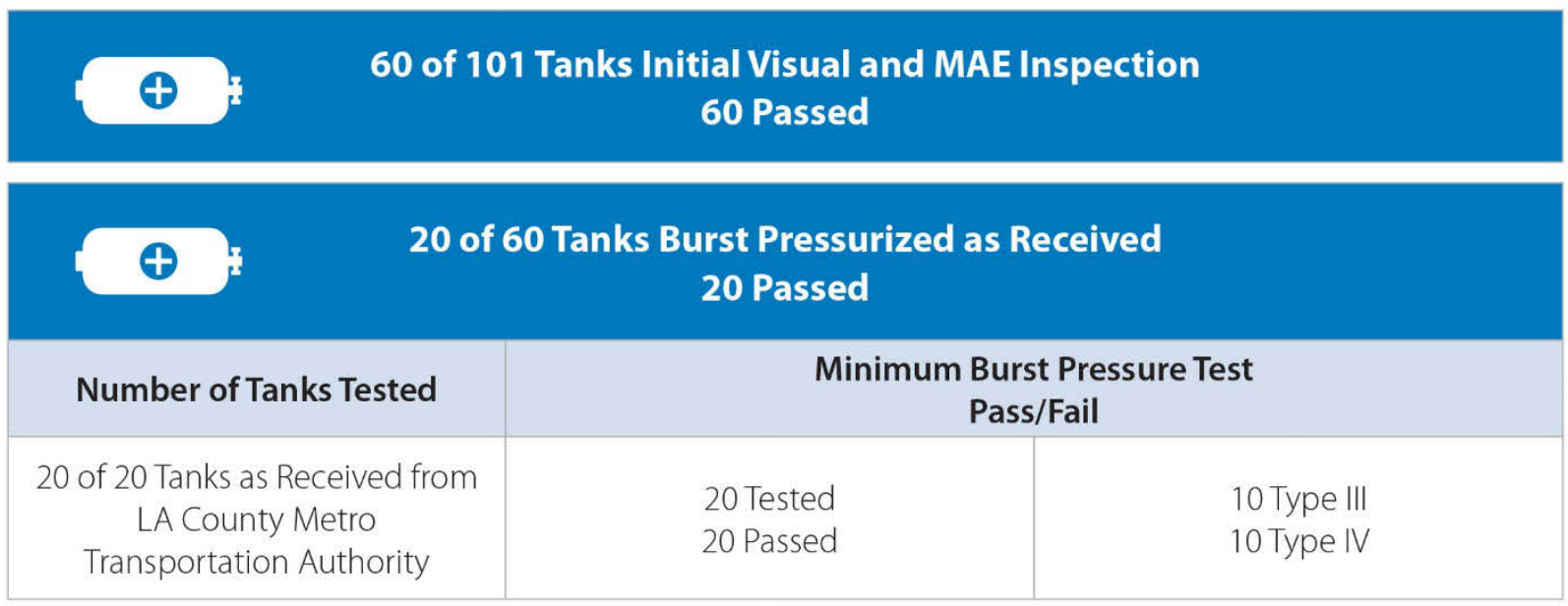

\begin{tabular}{|c|c|c|c|c|}
\hline \multirow{2}{*}{$\begin{array}{l}\text { Number of Tanks Tested } \\
8 \text { of } 20 \text { Tanks Notch Damaged }\end{array}$} & \multicolumn{2}{|c|}{$\begin{array}{c}\text { Hydraulic Fatigue Tested } \\
\text { to } 15,000 \text { Cycles } \\
\text { Pass/Fail }\end{array}$} & \multicolumn{2}{|c|}{$\begin{array}{c}\text { Minimum Burst Pressure Test } \\
\text { Pass/Fail }\end{array}$} \\
\hline & $\begin{array}{l}4 \text { Tested } \\
4 \text { Passed }\end{array}$ & $\begin{array}{l}2 \text { Type III } \\
\text { 2 Type IV }\end{array}$ & $\begin{array}{l}8 \text { Tested } \\
8 \text { Passed }\end{array}$ & $\begin{array}{l}\text { 4 Type III } \\
\text { 4 Type IV }\end{array}$ \\
\hline 4 of 20 Tanks Impact Damaged & $\begin{array}{l}2 \text { Tested } \\
2 \text { Passed }\end{array}$ & $\begin{array}{l}1 \text { Type III } \\
1 \text { Type IV }\end{array}$ & $\begin{array}{l}4 \text { Tested } \\
4 \text { Passed }\end{array}$ & $\begin{array}{l}2 \text { Type III } \\
\text { 2 Type IV }\end{array}$ \\
\hline $\begin{array}{c}4 \text { of } 8 \text { Tanks Local Impact } \\
\text { Damaged at Standard Height }\end{array}$ & $\begin{array}{l}2 \text { Tested } \\
2 \text { Passed }\end{array}$ & $\begin{array}{l}1 \text { Type III } \\
1 \text { Type IV }\end{array}$ & $\begin{array}{l}4 \text { Tested } \\
2 \text { Passed } \\
2 \text { Failed }\end{array}$ & $\begin{array}{l}2 \text { Type III } \\
2 \text { Type IV }\end{array}$ \\
\hline $\begin{array}{c}4 \text { of } 8 \text { Tanks Local Impact } \\
\text { Damaged at Double Height }\end{array}$ & $\begin{array}{l}2 \text { Tested } \\
2 \text { Passed }\end{array}$ & $\begin{array}{l}1 \text { Type III } \\
1 \text { Type IV }\end{array}$ & $\begin{array}{l}4 \text { Tested } \\
4 \text { Failed }\end{array}$ & $\begin{array}{l}2 \text { Type III } \\
2 \text { Type IV }\end{array}$ \\
\hline
\end{tabular}

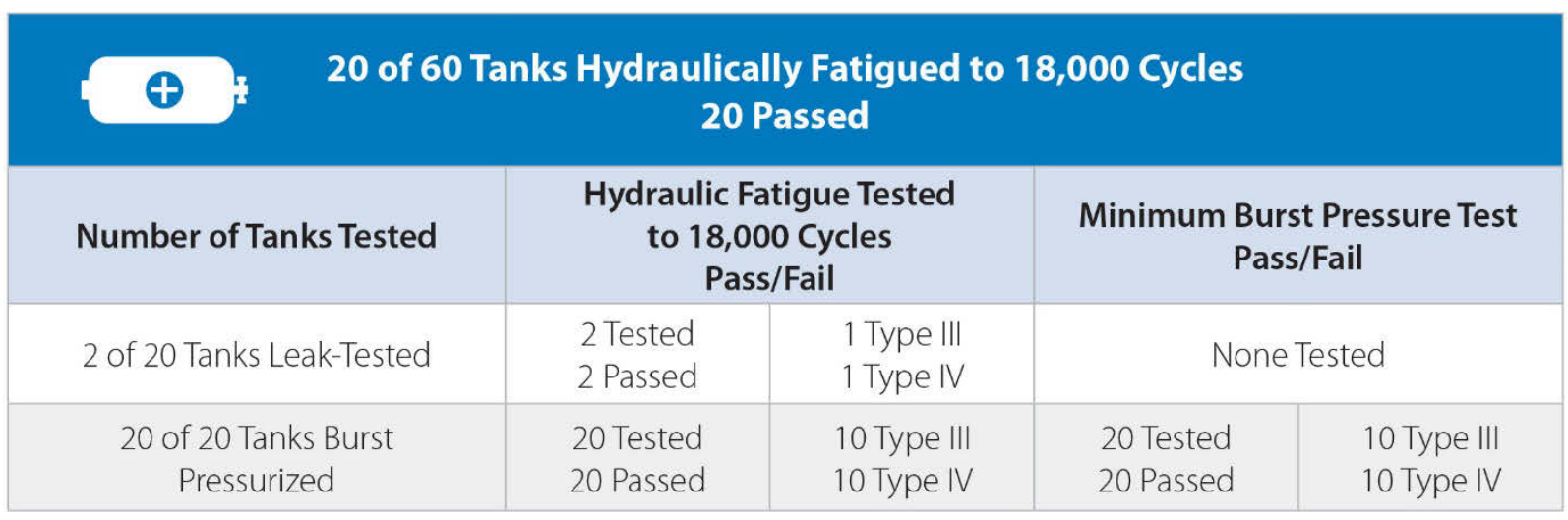

The results of the structural integrity testing of the Type III and Type IV CNG fuel tanks at the end of their defined useful life of 15 years from the LA County Metro Transportation Authority 
suggests potential opportunity of continued use of tanks, as the majority of the sample size met the minimum pressure requirements of NGV2 at EOL, as well as after additional hydraulic fatigue cycling and some artificial damage. Additional research and development with an expanded CNG fuel tank sample size to characterize tank integrity after experiencing a full service life in a variety of applications could further verify such potential. Visual inspection was not sufficient in identifying damage inflicted by a localized impact test on Type III and Type IV CNG fuel tanks, whereas a nondestructive evaluation method successfully assessed the structural integrity of the tanks and would not have compromised the original installation. 


\section{Table of Contents}

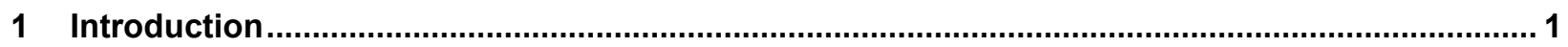

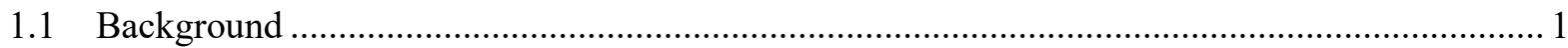

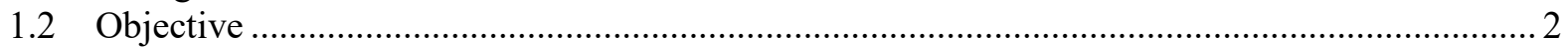

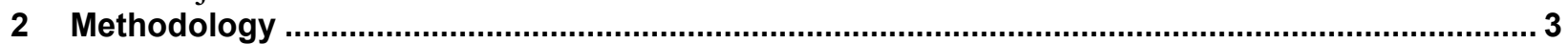

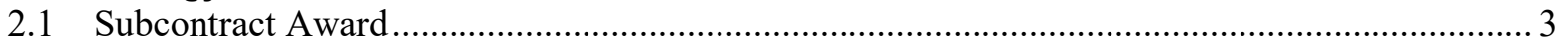

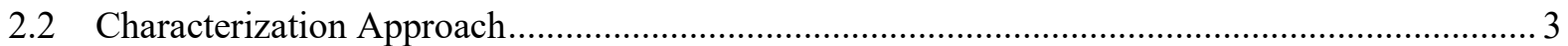

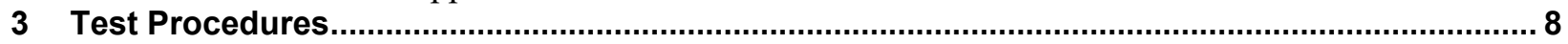

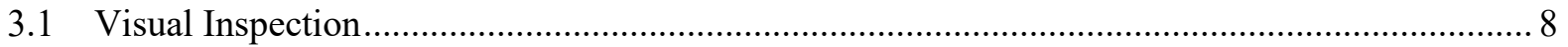

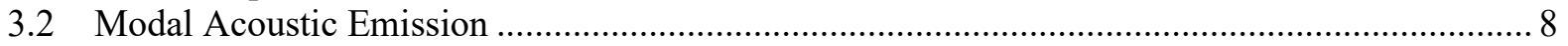

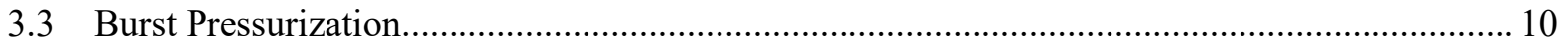

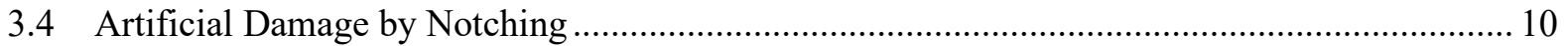

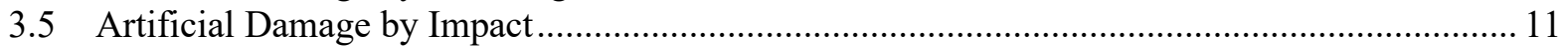

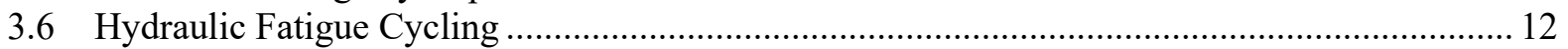

3.6.1 ISO 11439 Fatigue Cycle Method ................................................................... 12

3.6.2 FMVSS No. 304 Pressure Cycle Method................................................................... 13

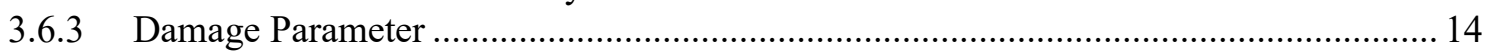

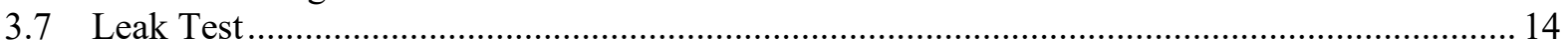

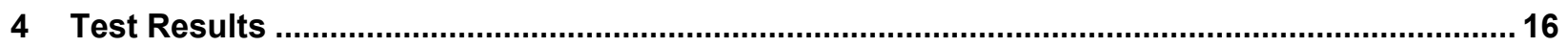

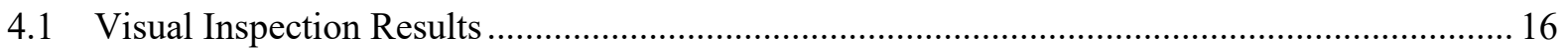

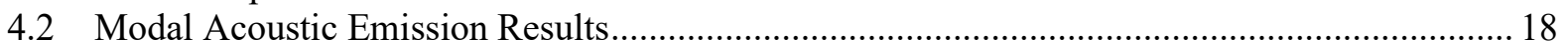

4.2.1 Examination of Tanks in Received Condition ........................................................ 18

4.2.2 Examination of Tanks Following Notch Damage ...................................................... 20

4.2.3 Examination of Tanks Following Impact Damage................................................. 21

4.3 Burst Pressurization Results of As-Received Tanks ................................................................. 22

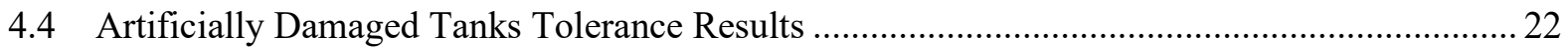

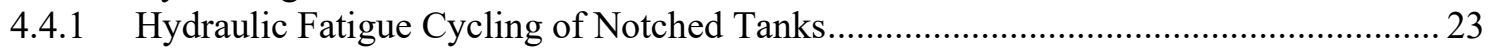

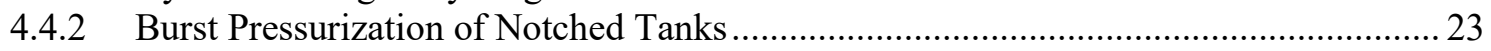

4.4.3 Hydraulic Fatigue Cycling of Impacted Tanks ......................................................... 24

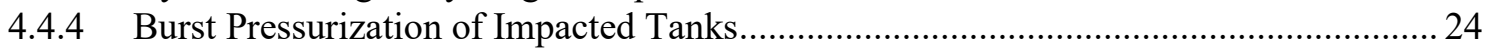

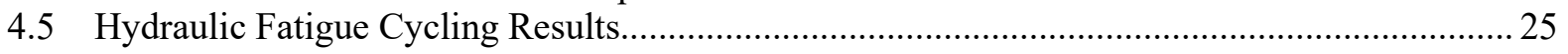

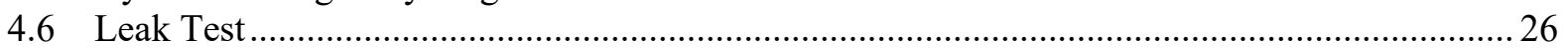

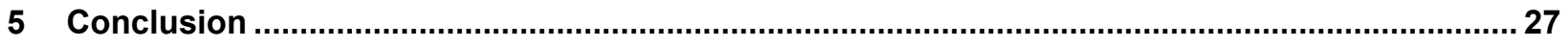

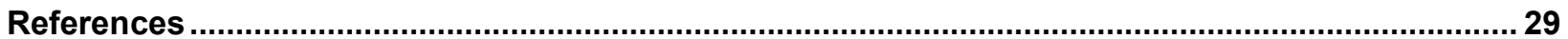




\section{List of Figures}

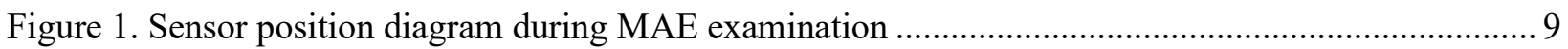

Figure 2. Pressure schedule for MAE examination followed by burst pressurization ............................... 10

Figure 3. (a) Representative short notch with deep depth and (b) representative long notch with shallow depth.

Figure 4. (1) Tank at testing height; (2) drop initiation of the tank; (3) tank dropping; (4) impact of the tank onto the steel angle iron

\section{List of Tables}

Table 1. Summary of Tests Conducted on Tanks as Received from LA Metro ........................................ 4

Table 2. Summary of Tests Conducted on Artificially Damaged Type III CNG Fuel Tanks...................... 5

Table 3. Summary of Tests Conducted on Artificially Damaged Type IV CNG Fuel Tanks ..................... 5

Table 4. Summary of Tests Conducted on Hydraulically Fatigued Tanks ............................................. 6

Table 5. Summary of Visual Inspection Results of Type III CNG Fuel Tanks ........................................ 16

Table 6. Summary of Visual Inspection Results of Type IV CNG Fuel Tanks....................................... 17

Table 7. Summary of MAE Examination Results of Type III CNG Fuel Tanks in Received Condition... 18

Table 8. Summary of MAE Examination Results of Type IV CNG Fuel Tanks in Received Condition... 19

Table 9. Summary of MAE Results of Tanks Following Notch Damage...............................................2 20

Table 10. Summary of MAE Results of Tanks Following Impact Damage ............................................ 21

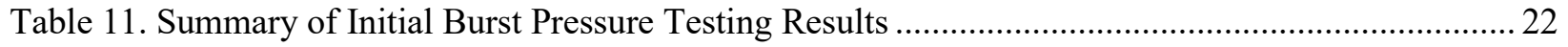

Table 12. Hydraulic Fatigue Cycling Test Results of Notched Tanks....................................................23

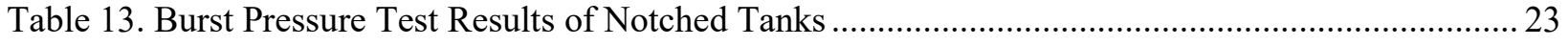

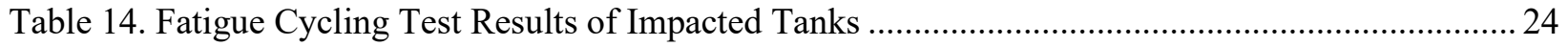

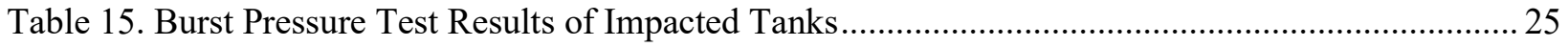

Table 16. Results of Tanks Hydraulically Fatigued Without Additional Damage ..................................26

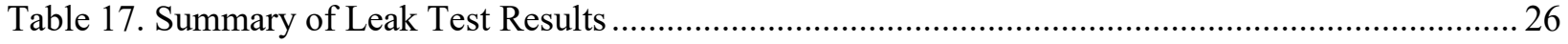




\section{Introduction}

The end-of-life (EOL) requirement of compressed natural gas $(\mathrm{CNG})$ fuel tanks can vary from the variable service life of the vehicle, compelling the vehicle owner to replace the fuel tank in compliance with the tank manufacturer's EOL requirements. CNG fuel tanks that need to be replaced before the end of the vehicle's service life are a financial burden to the vehicle owner and increases acute hazards related to the removal and reinstallation of the tanks, such as improper fitment of replacement fuel tanks, brackets, and mounting components. Federal Motor Vehicle Safety Standards (FMVSS) No. 304 requires a visual inspection of CNG fuel tanks (eCFR 2020), avoiding unnecessary removal and reinstallation of tanks to prevent such hazards. Removal and replacement of expired CNG fuel tanks also introduces concerns of resale of expired tanks or incorrect disposal of CNG fuel tanks.

There are no FMVSS that define the EOL requirement for CNG fuel tanks as they are defined by the manufacturer, and there are limited and inconsistent enforcement efforts to ensure vehicle owners adhere to the EOL requirements for CNG fuel tanks. Therefore, it is not uncommon for $\mathrm{CNG}$ vehicles to continue utilizing CNG fuel tanks that have surpassed their defined EOL requirements.

In support of the U.S. Department of Energy, the National Renewable Energy Laboratory (NREL) led this study to investigate the integrity of CNG fuel tanks under routine operating conditions at the end of their defined useful life in order to better identify, understand, and mitigate safety risks and address barriers and opportunities related to CNG storage onboard vehicles. This section provides an overview of the background and objective of the project.

\subsection{Background}

Natural gas was designated as an alternative fuel to gasoline under the Energy Policy Act of 1992 (AFDC 2020). Due to its domestic abundance, low cost, and lower engine emissions, CNG is a widely used alternative fuel for both light- and heavy-duty vehicles. Currently, there are approximately 150,000 natural gas vehicles in service in the United States, while an estimated 15.2 million vehicles operate on natural gas worldwide (CSA/ANSI 2019).

Compressed gas cylinders are an integral part of a CNG vehicle's fuel system. These fuel tanks are typically manufactured to meet CSA Group/American National Standards Institute's (CSA/ANSI's) CSA/ANSI NGV 2-2019 (NGV2) standard as it defines design and certification requirements for natural gas vehicle (NGV) onboard fuel tanks. NGV2 is an American National Standard processed under the canvass method, in accordance with procedures of ANSI. NGV2 states that the defined useful life of the CNG fuel tanks shall be specified by the tank manufacturer and shall be greater than 10 years and less than 25 years.

There are four CNG fuel tank cylinder types. Type I CNG cylinders are completely made of either aluminum or steel metal. Type II CNG cylinders are manufactured with a metal liner reinforced by glass or carbon fiber composite wrap around the middle (also referred to as "hoop wrap"). Type III CNG cylinders are also manufactured with a metal liner but are reinforced with a full composite wrap encompassing the entire cylinder. Type IV cylinders are manufactured 
with a plastic, gastight liner reinforced by a full composite wrap encompassing the entire cylinder.

The vehicle owner is required to replace CNG fuel tanks in compliance with the tank manufacturer's EOL requirements. However, the removal and replacement of the fuel tanks may introduce critical hazards such as improper fitment of the tanks, brackets, and mounting components that could potentially cause probable failure modes to the system. In addition to safety hazards, removal and replacement of expired fuel tanks on CNG vehicles with remaining service life is a burdened expense to the vehicle owner and tends to compound for fleets with multiple CNG vehicles that likely have multiple CNG fuel tanks per vehicle. Removal and replacement of CNG tanks tend to be cost-prohibitive for fleets, sometimes resulting in utilization of CNG tanks beyond defined EOL.

\subsection{Objective}

Due to the continued use of CNG fuel tanks beyond their defined EOL, NREL initiated this study on behalf of the U.S. Department of Energy to investigate the integrity of CNG fuel tanks under routine operating conditions at the end of their defined useful life. These data will assist the industry to better identify, quantify, and alleviate the safety risks associated with CNG tanks in operation beyond their defined EOL, in addition to addressing barriers and opportunities related to CNG storage onboard vehicles. 


\section{Methodology}

\subsection{Subcontract Award}

On July 1, 2016, NREL submitted a request for proposal number RGJ-6-62575-01 for characterization of CNG fuel tanks at the end of their defined service life. The winning subcontractor was responsible for identifying transit agencies or fleets that would be able to provide CNG fuel tanks at their defined EOL, provide a list of fuel tanks to be tested, provide a test plan for characterization of the fuel tanks to understand their structural integrity, conduct the testing, and produce a final report of the test results. On September 30, 2016, subcontract number AGJ-7-62575-01 was awarded to Digital Wave Corporation of Centennial, Colorado.

In October 2017, a work stop order was put in place due to unforeseen budget impacts. The subcontractor was not able to complete the defined test plan and paused the work in hopes of being able to continue once funding was available again. Approximately one year after work ceased, the contract was reinstated, and the subcontractor agreed to complete the testing with minimal changes to the originally defined test plan. Testing resumed in March 2019 and was complete per the contract deliverables in October 2019.

\subsection{Characterization Approach}

The physical durability of Type III and Type IV CNG fuel tanks from the Los Angeles (LA) County Metropolitan Transportation Authority were evaluated to characterize the fuel tank's structural integrity after experiencing a full service life of 15 years in transit bus application. In addition to the durability testing performed on the fuel tanks, modal acoustic emission (MAE), a nondestructive evaluation method, was utilized to assess the structural integrity of the tanks where the results were then compared to visual inspection results.

A total of $101 \mathrm{CNG}$ fuel tanks at the end of their defined useful life were provided by the LA Metro Transportation Authority. Fifty tanks were Type III cylinders and 51 were Type IV cylinders. Each tank was used in transit bus applications, where they were stored onboard in covered housing. The exact service history of each fuel tank was unknown. However, each tank was estimated to have been cycled from 1,000 to 4,400 pounds per square inch gauge (psig), 6 times per week for 15 years, resulting in an estimated total of 4,680 fatigue cycles over the useful life of each tank. A total sample size of 60 tanks - 30 Type III and 30 Type IV-were subjected to testing. Ten tanks of each design type were concluded to be statistically significant for EOL burst pressurization and hydraulic fatigue cycling as defined by the subcontractor, and the number of tanks subjected to artificial damage provided a single replicate of each design type for sample control.

Once selected at random for testing, all $60 \mathrm{CNG}$ fuel tanks were visually inspected according to the U.S. fuel system inspection standard Compressed Gas Association (CGA) C-6.4, and CGA C-6.2 if the tank was a Type III cylinder. All tanks were then examined by MAE to further assess the structural integrity before testing. Twenty of the tanks, 10 Type III and 10 Type IV, were pressurized until burst according to NGV2 to establish a baseline understanding of the tank's structural integrity at the defined EOL, in their as received condition. Table 1 summarizes the tests conducted on the tanks as received from LA Metro Transportation Authority. 
Table 1. Summary of Tests Conducted on Tanks as Received from LA Metro

\begin{tabular}{lllllll}
\hline $\begin{array}{c}\text { Tank } \\
\text { Count }\end{array}$ & $\begin{array}{c}\text { Design } \\
\text { Type }\end{array}$ & $\begin{array}{c}\text { Serial } \\
\text { Number }\end{array}$ & $\begin{array}{c}\text { Manufacture } \\
\text { Date }\end{array}$ & $\begin{array}{c}\text { Visual \& MAE } \\
\text { Inspection }\end{array}$ & $\begin{array}{c}\text { Artificial } \\
\text { Damage }\end{array}$ & $\begin{array}{c}\text { Burst } \\
\text { Pressure }\end{array}$ \\
\hline 1 & III & ALT810N-2565 & Nov. 2001 & YES & NO & YES \\
\hline 2 & III & ALT810N-3991 & March 2002 & YES & NO & YES \\
\hline 3 & III & ALT810N-3993 & March 2002 & YES & NO & YES \\
\hline 4 & III & ALT810N-1976 & Sept. 2001 & YES & NO & YES \\
\hline 5 & III & ALT810N-2099 & Oct. 2001 & YES & NO & YES \\
\hline 6 & III & ALT810N-2107 & Oct. 2001 & YES & NO & YES \\
\hline 7 & III & ALT810N-3858 & March 2002 & YES & NO & YES \\
\hline 8 & III & ALT810N-3884 & March 2002 & YES & NO & YES \\
\hline 9 & III & ALT810N-4049 & March 2002 & YES & NO & YES \\
\hline 10 & III & ALT810N-2189 & Oct. 2001 & YES & NO & YES \\
\hline 11 & IV & $314-051$ & Oct. 2000 & YES & NO & YES \\
\hline 12 & IV & $314-144$ & Oct. 2000 & YES & NO & YES \\
\hline 13 & IV & $316-007$ & Oct. 2000 & YES & NO & YES \\
\hline 14 & IV & $319-037$ & Oct. 2000 & YES & NO & YES \\
\hline 15 & IV & $305-163$ & Aug. 2000 & YES & NO & YES \\
\hline 16 & IV & $309-181$ & Aug. 2000 & YES & NO & YES \\
\hline 17 & IV & $314-050$ & Oct. 2000 & YES & NO & YES \\
\hline 18 & IV & $309-026$ & Aug. 2000 & YES & NO & YES \\
\hline 19 & IV & $305-160$ & Aug. 2000 & YES & NO & YES \\
\hline 20 & IV & $319-012$ & Oct. 2000 & YES & NO & YES \\
\hline
\end{tabular}

An additional 20 tanks were then subjected to artificial damage via notch and impact procedures followed by hydraulic fatigue cycling and burst pressure tests to understand the tank's structural integrity at the defined EOL in comparison to the NGV2 design and performance standard. The test procedure used to inflict notch damage was defined in Section A.17 of International Organization for Standardization (ISO) 11439 (ISO 2000) and the test procedure to inflict impact damage was done according to Section A.20 of ISO 11439 with additional modifications to increase the severity of the impact damage to better represent risks from in-service operating conditions. After artificial damage, some tanks were then additionally cycled per hydraulic fatigue cycling defined in Sections A.17 and A.20 of ISO 11439. Finally, all 20 of the artificially damaged tanks were burst-tested according to NGV2. The tests conducted on the artificially damaged and additionally cycled tanks are summarized in Table 2 and Table 3. 
Table 2. Summary of Tests Conducted on Artificially Damaged Type III CNG Fuel Tanks

\begin{tabular}{lllllll}
\hline $\begin{array}{l}\text { Tank } \\
\text { Count }\end{array}$ & Serial Number & $\begin{array}{l}\text { Pre-Damage } \\
\text { Visual \& MAE } \\
\text { Inspection }\end{array}$ & $\begin{array}{l}\text { Artificial } \\
\text { Damage Type }\end{array}$ & $\begin{array}{l}\text { Hydraulic } \\
\text { Fatigue } \\
\text { Cycling }\end{array}$ & $\begin{array}{l}\text { Post-Damage } \\
\text { Visual \& MAE } \\
\text { Inspection }\end{array}$ & $\begin{array}{l}\text { Post-Damage } \\
\text { Burst Testing }\end{array}$ \\
\hline 1 & ALT810N-3324 & YES & Impact & NO & YES & YES \\
\hline 2 & ALT810N-2188 & YES & Impact & YES & YES & YES \\
\hline 3 & ALT810N-4105 & YES & Localized Impact & NO & YES & YES \\
\hline 4 & ALT810N-2562 & YES & Localized Impact & YES & YES & YES \\
\hline 5 & ALT810N-2191 & YES & $\begin{array}{l}\text { Localized Impact } \\
\text { at Double Height }\end{array}$ & NO & YES & YES \\
\hline 6 & ALT810N-2104 & YES & $\begin{array}{l}\text { Localized Impact } \\
\text { at Double Height }\end{array}$ & YES & YES & YES \\
\hline 7 & ALT810N-3651 & YES & Notched & NO & YES & YES \\
\hline 8 & ALT810N-3742 & YES & Notched & NO & YES & YES \\
\hline 9 & ALT810N-1995 & YES & Notched & YES & YES & YES \\
\hline 10 & ALT810N-2744 & YES & Notched & YES & YES & YES \\
\hline
\end{tabular}

Table 3. Summary of Tests Conducted on Artificially Damaged Type IV CNG Fuel Tanks

\begin{tabular}{lllllll}
\hline $\begin{array}{l}\text { Tank } \\
\text { Count }\end{array}$ & $\begin{array}{l}\text { Serial } \\
\text { Number }\end{array}$ & $\begin{array}{l}\text { Pre-Damage } \\
\text { Visual \& MAE } \\
\text { Inspection }\end{array}$ & $\begin{array}{l}\text { Artificial Damage } \\
\text { Type }\end{array}$ & $\begin{array}{l}\text { Hydraulic } \\
\text { Fatigue } \\
\text { Cycling }\end{array}$ & $\begin{array}{l}\text { Post-damage } \\
\text { Visual \& MAE } \\
\text { Inspection }\end{array}$ & $\begin{array}{l}\text { Post-Damage } \\
\text { Burst Testing }\end{array}$ \\
\hline 1 & $309-022$ & YES & Impact & NO & YES & YES \\
\hline 2 & $305-164$ & YES & Impact & YES & YES & YES \\
3 & $305-159$ & YES & Localized Impact & NO & YES & YES \\
\hline 4 & $319-001$ & YES & Localized Impact & YES & YES & YES \\
\hline 5 & $309-023$ & YES & $\begin{array}{l}\text { Localized Impact at } \\
\text { Double Height }\end{array}$ & NO & YES & YES \\
\hline 6 & $313-047$ & YES & Localized Impact at & YES & YES & YES \\
\hline 7 & $319-006$ & YES & Notched & NO & YES & YES \\
\hline 8 & $316-008$ & YES & Notched & NO & YES & YES \\
\hline 9 & $316-014$ & YES & Notched & YES & YES & YES \\
10 & $309-117$ & YES & Notched & YES & YES & YES \\
\hline
\end{tabular}

Another 20 tanks were subjected to hydraulic fatigue cycling followed by a burst pressurization test to simulate continued use of the tanks beyond their defined EOL and understand the tank's structural integrity in comparison to NGV2 design and performance standard for tank burst requirement at the time of manufacture. The hydraulic fatigue cycling consisted of a total of 18,000 cycles per FMVSS No. 304 to simulate approximately 24 years of additional service, assuming 750 fills per year. Two of the tanks that were hydraulically fatigued were also leak- 
tested according to NGV2 before being burst-tested. Table 4 is a summary of the tests conducted on the tanks that were hydraulically fatigued.

Table 4. Summary of Tests Conducted on Hydraulically Fatigued Tanks

\begin{tabular}{|c|c|c|c|c|c|c|c|c|c|}
\hline $\begin{array}{l}\text { Tank } \\
\text { Count }\end{array}$ & $\begin{array}{l}\text { Design } \\
\text { Type }\end{array}$ & $\begin{array}{l}\text { Serial } \\
\text { Number }\end{array}$ & $\begin{array}{l}\text { Manufact } \\
\text { ure Date }\end{array}$ & $\begin{array}{l}\text { Initial } \\
\text { Visual \& } \\
\text { MAE } \\
\text { Inspection }\end{array}$ & $\begin{array}{l}\text { Artificial } \\
\text { Damage }\end{array}$ & $\begin{array}{l}\text { Hydraulic } \\
\text { Fatigue } \\
\text { Cycled }\end{array}$ & $\begin{array}{l}\text { Post- } \\
\text { Cycling } \\
\text { Visual \& } \\
\text { MAE } \\
\text { Inspect- } \\
\text { ion }\end{array}$ & $\begin{array}{l}\text { Burst } \\
\text { Pressure }\end{array}$ & $\begin{array}{l}\text { Leak } \\
\text { Tested }\end{array}$ \\
\hline 1 & III & $\begin{array}{l}\text { ALT810 } \\
\text { N-3653 }\end{array}$ & $\begin{array}{l}\text { Feb. } \\
2002\end{array}$ & YES & NO & YES & YES & YES & NO \\
\hline 2 & III & $\begin{array}{l}\text { ALT810 } \\
\text { N-2351 }\end{array}$ & $\begin{array}{l}\text { Oct. } \\
2001\end{array}$ & YES & NO & YES & YES & YES & YES \\
\hline 3 & III & $\begin{array}{l}\text { ALT810 } \\
\text { N-3733 }\end{array}$ & $\begin{array}{l}\text { March } \\
2002\end{array}$ & YES & NO & YES & YES & YES & NO \\
\hline 4 & III & $\begin{array}{l}\text { ALT810 } \\
\text { N-2353 }\end{array}$ & $\begin{array}{l}\text { Oct. } \\
2001\end{array}$ & YES & NO & YES & YES & YES & NO \\
\hline 5 & III & $\begin{array}{l}\text { ALT810 } \\
\text { N-2740 }\end{array}$ & $\begin{array}{l}\text { Dec. } \\
2001\end{array}$ & YES & NO & YES & YES & YES & NO \\
\hline 6 & III & $\begin{array}{l}\text { ALT810 } \\
\text { N-2403 }\end{array}$ & $\begin{array}{l}\text { Oct. } \\
2001\end{array}$ & YES & NO & YES & YES & YES & NO \\
\hline 7 & III & $\begin{array}{l}\text { ALT810 } \\
\text { N-3735 }\end{array}$ & $\begin{array}{l}\text { March } \\
2002\end{array}$ & YES & NO & YES & YES & YES & NO \\
\hline 8 & III & $\begin{array}{l}\text { ALT810 } \\
\text { N-3323 }\end{array}$ & $\begin{array}{l}\text { Feb. } \\
2002\end{array}$ & YES & NO & YES & YES & YES & NO \\
\hline 9 & III & $\begin{array}{l}\text { ALT810 } \\
\text { N-2996 }\end{array}$ & $\begin{array}{l}\text { Dec. } \\
2001\end{array}$ & YES & NO & YES & YES & YES & NO \\
\hline 10 & III & $\begin{array}{l}\text { ALT810 } \\
\text { N-3326 }\end{array}$ & $\begin{array}{l}\text { Feb. } \\
2002\end{array}$ & YES & NO & YES & YES & YES & NO \\
\hline 11 & IV & $313-063$ & $\begin{array}{l}\text { Oct. } \\
2000\end{array}$ & YES & NO & YES & YES & YES & NO \\
\hline 12 & IV & $309-032$ & $\begin{array}{l}\text { Aug. } \\
2000\end{array}$ & YES & NO & YES & YES & YES & NO \\
\hline 13 & IV & $319-020$ & $\begin{array}{l}\text { Oct. } \\
2000\end{array}$ & YES & NO & YES & YES & YES & NO \\
\hline 14 & IV & $313-046$ & $\begin{array}{l}\text { Sept. } \\
2000\end{array}$ & YES & NO & YES & YES & YES & NO \\
\hline 15 & IV & $309-025$ & $\begin{array}{l}\text { Aug. } \\
2000\end{array}$ & YES & NO & YES & YES & YES & NO \\
\hline 16 & IV & $309-186$ & $\begin{array}{l}\text { Aug. } \\
2000\end{array}$ & YES & NO & YES & YES & YES & YES \\
\hline 17 & IV & $313-045$ & $\begin{array}{l}\text { Sept. } \\
2000\end{array}$ & YES & NO & YES & YES & YES & NO \\
\hline
\end{tabular}




\begin{tabular}{|c|c|c|c|c|c|c|c|c|c|}
\hline $\begin{array}{l}\text { Tank } \\
\text { Count }\end{array}$ & $\begin{array}{l}\text { Design } \\
\text { Type }\end{array}$ & $\begin{array}{l}\text { Serial } \\
\text { Number }\end{array}$ & $\begin{array}{l}\text { Manufact } \\
\text { ure Date }\end{array}$ & $\begin{array}{l}\text { Initial } \\
\text { Visual \& } \\
\text { MAE } \\
\text { Inspection }\end{array}$ & $\begin{array}{l}\text { Artificial } \\
\text { Damage }\end{array}$ & $\begin{array}{l}\text { Hydraulic } \\
\text { Fatigue } \\
\text { Cycled }\end{array}$ & $\begin{array}{l}\text { Post- } \\
\text { Cycling } \\
\text { Visual \& } \\
\text { MAE } \\
\text { Inspect- } \\
\text { ion }\end{array}$ & $\begin{array}{l}\text { Burst } \\
\text { Pressure }\end{array}$ & $\begin{array}{l}\text { Leak } \\
\text { Tested }\end{array}$ \\
\hline 18 & IV & $319-007$ & $\begin{array}{l}\text { Oct. } \\
2000\end{array}$ & YES & NO & YES & YES & YES & NO \\
\hline 19 & IV & $319-051$ & $\begin{array}{l}\text { Oct. } \\
2000\end{array}$ & YES & NO & YES & YES & YES & NO \\
\hline 20 & IV & $314-048$ & $\begin{array}{l}\text { Oct. } \\
2000\end{array}$ & YES & NO & YES & YES & YES & NO \\
\hline
\end{tabular}




\section{Test Procedures}

This section summarizes the test procedures conducted on the $60 \mathrm{CNG}$ fuel tanks for EOL characterization.

\subsection{Visual Inspection}

Prior to any testing, all $60 \mathrm{CNG}$ fuel tanks were visually inspected according to CGA C-6.4 and CGA C-6.2 if the tank was a Type III cylinder. The fuel system inspection standard in the United States utilized by the CNG fuel vehicle industry is CGA C-6.4. It provides guidance on assessing the fuel storage containers (fuel tanks) for dents, dings, cuts, gouges, and scrapes, and other such damage, as well as signs of leakage of the fuel tanks or compromised cap, valve, cover, shield, regulator, lines, filtration, brackets, and mounting components. The visual inspection is typically conducted while the fuel tank remains mounted on the vehicle, where cameras and/or mirrors may be used as tools for the inspection. A qualified CNG fuel system inspector typically conducts the visual inspection of the CNG fuel system once per year, as required by FMVSS No. 304, as well as before the CNG vehicle is placed in service and after any thermal event or accident. CGA C-6.2 standard addresses the techniques for visual inspection and requalification of composite overwrapped high-pressure cylinders and provides guidance on internal visual inspection of liners specific to Type III cylinders that is not covered in CGA C-6.4.

\subsection{Modal Acoustic Emission}

All 60 CNG fuel tanks were inspected by MAE examination both before and after artificial damage and hydraulic fatigue cycling. Criteria for the MAE acceptance or rejection of the fuel tanks were defined by ISO Technical Standard 19016 and U.S. Department of Transportation Pipeline and Hazardous Materials Safety Administration (PHMSA) standard "Modal Acoustic Emission (MAE) Examination Specification for Requalification of Composite Overwrapped Pressure Vessels (cylinders and tubes)." During MAE examination, the tanks were pressurized to a defined schedule and piezoelectric sensors were attached to the external surface of the tank, where they passively detected stress waves emanating from a given damage mechanism. Figure 1 illustrates the sensor location for both Type III and Type IV cylinders during MAE examination. 


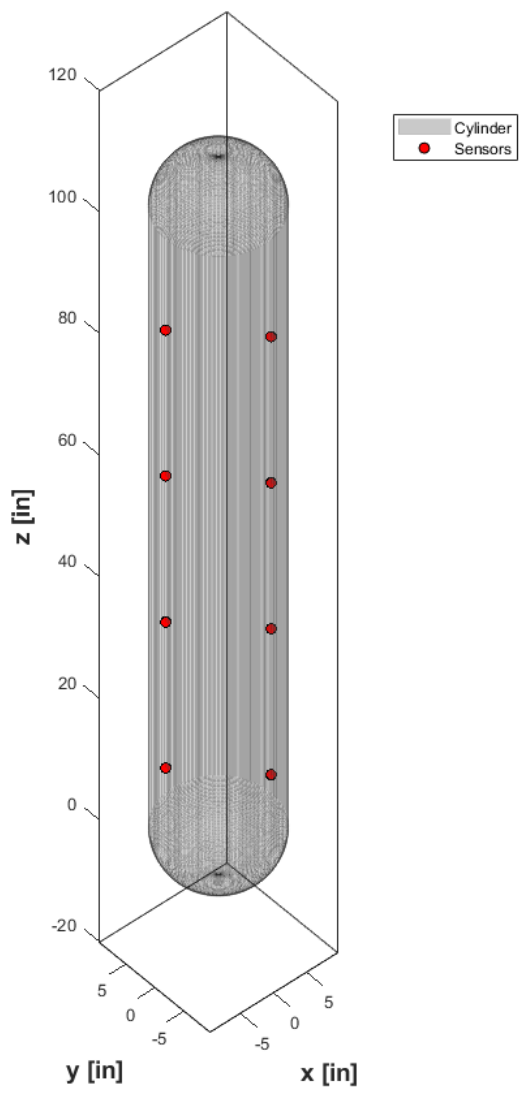

Figure 1. Sensor position diagram during MAE examination

Frequency and damage mechanics analyses were conducted to determine the type of damage, as well as the significance of the damage to the structural integrity of the tank. For this study, a Digital Wave Corporation digital module system was used to capture the stress waveforms and facilitate the MAE examination.

Figure 2 illustrates the pressure schedule used to perform the MAE examination on all the CNG tanks that underwent inspection. All tanks had a defined service pressure of 3,600 psig.

Therefore, 4,700 psig was the pressure level for the $130 \%$ hold, and 5,400 psig was the pressure level for the holds at $150 \%$. 


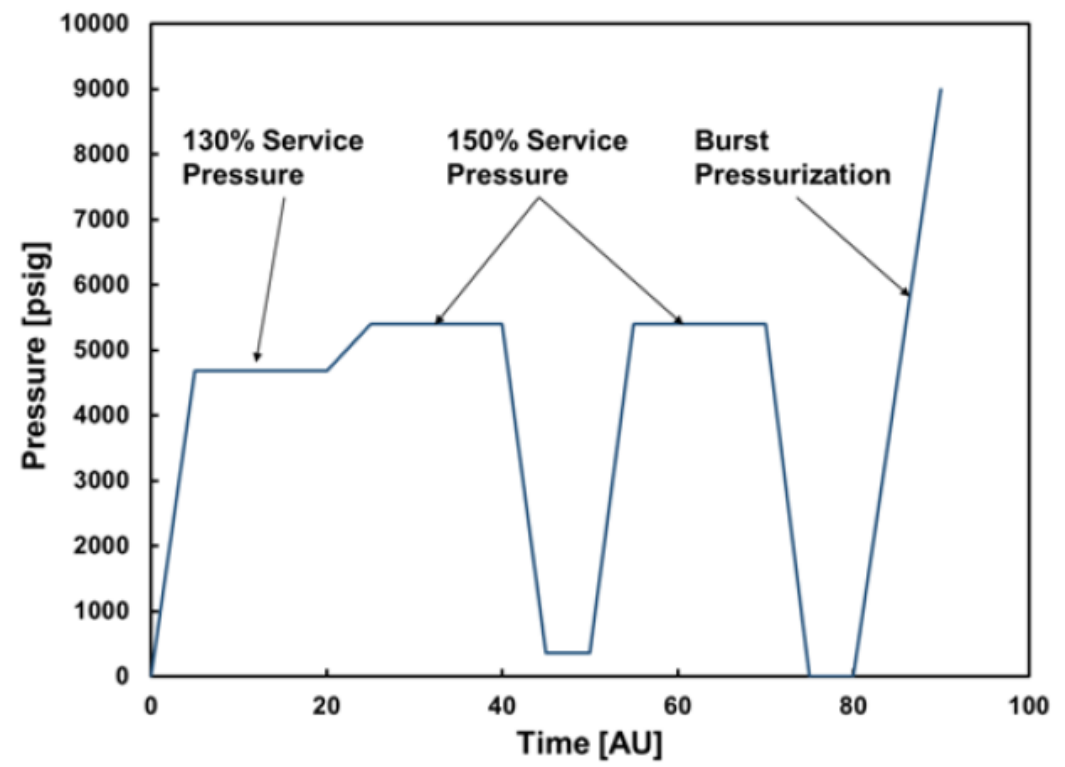

Figure 2. Pressure schedule for MAE examination followed by burst pressurization

\subsection{Burst Pressurization}

Twenty CNG tanks - 10 Type III and 10 Type IV - were randomly sampled from the total population of 101 tanks for EOL burst pressurization testing. Prior to burst testing, all tanks were visually inspected per CGA C-6.2 and CGA C-6.4, where all tanks passed according to the acceptance criteria.

A 20,000-psig full-scale pressure transducer was used to monitor the tank's pressure during testing. The pressure transducer was connected at the end of the tank, opposite the hydraulic pump, to avoid "pressure hammering" from the hydraulic pump and to achieve a clear pressure signal. The cylinders were hydrostatically pressurized until burst, where the minimum burst pressure requirement of 8,100 psig from NGV2 was referenced as the acceptance criteria.

\subsection{Artificial Damage by Notching}

Eight of 20 artificially damaged tanks were notched before pressurized until burst. Two notches were imposed along the axial direction of four Type III cylinders and four Type IV cylinders according to Section A.17 of ISO 11439. One notch was shorter in length with a deeper depth, and the second notch was longer in length with a shallower depth. The shorter notch was 1.0 inch long and 0.05 inches deep, whereas the longer notch was 8.0 inches long and 0.03 inches deep, as show in Figure 3. 


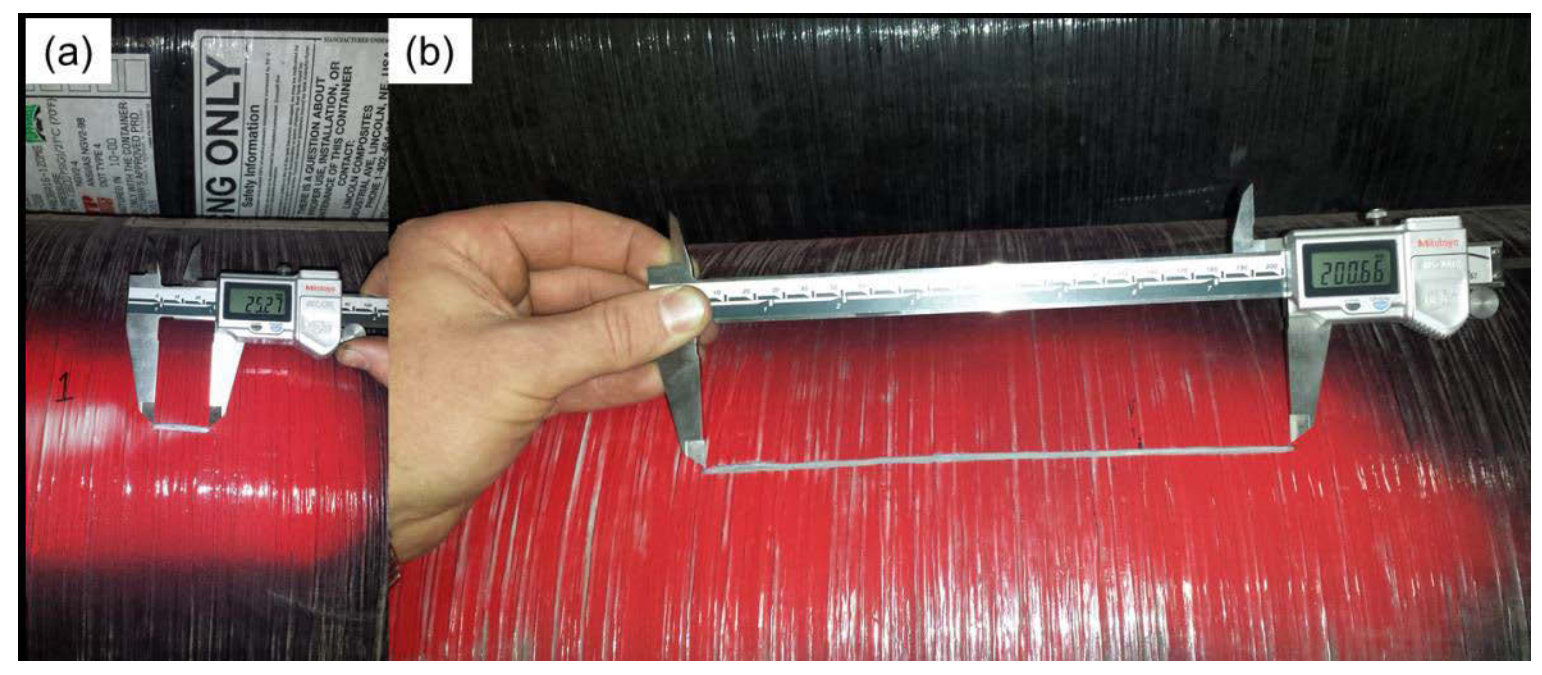

Figure 3. (a) Representative short notch with deep depth and (b) representative long notch with shallow depth

\subsection{Artificial Damage by Impact}

Twelve of the $20 \mathrm{CNG}$ fuel tanks were artificially damaged through horizontal impact events as defined in Section A.20 of ISO 11439. Four of the tanks - two Type III cylinders and two Type IV cylinders - were subjected to impact damage as specified in the test procedure by dropping the tanks from the specified height onto a flat concrete surface. In order to represent a worst-case scenario of real-world failure modes of impact damage experienced by CNG fuel tanks in service, the remaining cylinders were dropped onto a modified surface from an adjusted height from that defined in the test procedure. Two Type III and two Type IV fuel tanks were dropped onto a 4 in. $x 6$ in. $x 36$ in. piece of angled steel located on the ground at the impact location. The angled steel localized the impact onto the tank to increase the severity of the damage. Another two additional Type III and two Type IV fuel tanks were dropped from twice the defined height onto a $4 \times 6 \times 36$-in. piece of angled steel located on the ground at the impact location, as the increased height from which the tanks were dropped doubled the amount of potential energy of the impact event. These modified test conditions were a better representation of severe damage inflicted onto CNG fuel tanks in actual operating environments. Figure 4 depicts a time lapse of the representative localized impact event onto the steel angle iron. 


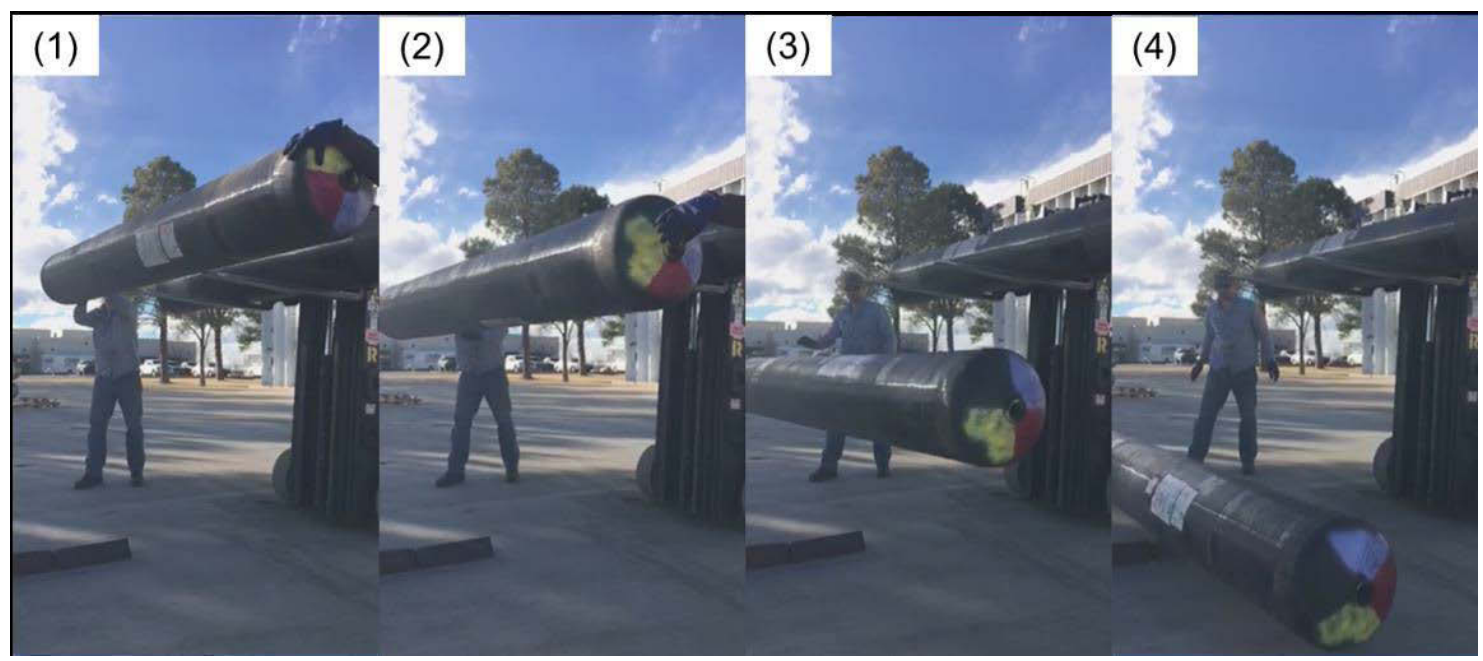

Figure 4. (1) Tank at testing height; (2) drop initiation of the tank; (3) tank dropping; (4) impact of the tank onto the steel angle iron

\subsection{Hydraulic Fatigue Cycling}

Hydraulic fatigue cycling was conducted in order to simulate extended service life for the CNG fuel tanks. Two different methods were used for hydraulic fatigue cycling: the internationally recognized design standard ISO 11439 (ISO 2000) for the 10 tanks that had been artificially damaged, and U.S. FMVSS No. 304 for the 20 tanks that were cycled as received from LA Metro Transportation Authority. The method defined in ISO 11439 was used for the artificially damaged tanks in continuation of the notching and impact protocols, as FMVSS No. 304 does not include requirements for impact or notch tolerance testing.

In order to monitor the mechanical stiffness during hydraulic fatigue cycle testing according to both test methods and to quantify the total accumulated microstructural damage of the tanks, the subcontractor defined and calculated a damage parameter. The details of these methods and the damage parameter are further described in the following sections.

\subsubsection{ISO 11439 Fatigue Cycle Method}

Following artificial damage procedures of notch and impact events, 10 of the 20 damaged tanks were subjected to hydraulic fatigue cycling according to the requirements of Sections A.17 and A.20 of ISO 11439. These tanks were hydraulically pressurized from a minimum of $10 \%$ of defined service pressure (360 psig) to a maximum of 105\% of defined service pressure (a high pressure set point of 3,780 psig). This fatigue cycling consisted of a total of 15,000 cycles at a rate of approximately $0.007 \mathrm{~Hz}$. Figure 5 illustrates the measured pressure trace of four of these representative fatigue cycles. 


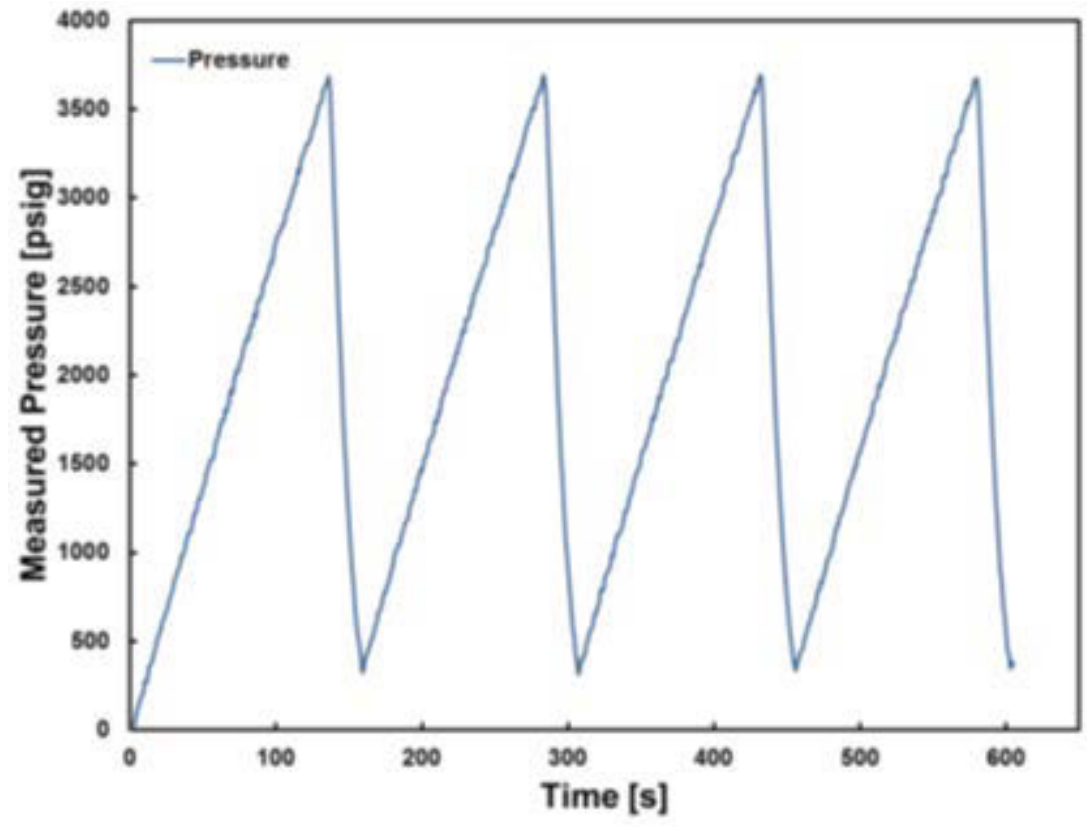

Figure 5. Pressure trace of four fatigue cycles

The total 15,000 cycles simulated approximately 20 years of additional service, assuming 750 fills per year. Every $2,250^{\text {th }}$ cycle, representative of 3 years of service life, an overload fatigue cycle to $150 \%$ of service pressure (resulting in 5,400 psig, representative of a test pressure cycle) was placed on the cylinders to represent real-world periodic pressurization inspection of the tank to test pressure.

\subsubsection{FMVSS No. 304 Pressure Cycle Method}

The 20 tanks that were subjected to hydraulic fatigue cycling followed by a burst test to simulate continued use of the tanks beyond their defined EOL were pressure cycled according to Section 8.1.1 of FMVSS No. 304 (e-CFR 2020).

Each tank was subjected to 13,000 fatigue cycles from a service pressure of 3,600 psig to a maximum of $10 \%$ of the service pressure (resulting in $360 \mathrm{psig}$ ). Every $2,250^{\text {th }}$ cycle, representative of 3 years of service life, an overload fatigue cycle to $150 \%$ of service pressure (resulting in 5,400 psig, representative of a test pressure cycle) was introduced to represent a periodic pressurization inspection. After the 13,000 cycles to service pressure, including the overload cycle, the tanks were subjected to 5,000 cycles of $125 \%$ of service pressure to a maximum of $10 \%$ of the service pressure (resulting in $360 \mathrm{psig}$ ). These 5,000 cycles included two overload cycles every 2,250 cycles. Figure 6 illustrates the pressure trace of these fatigue cycles. 


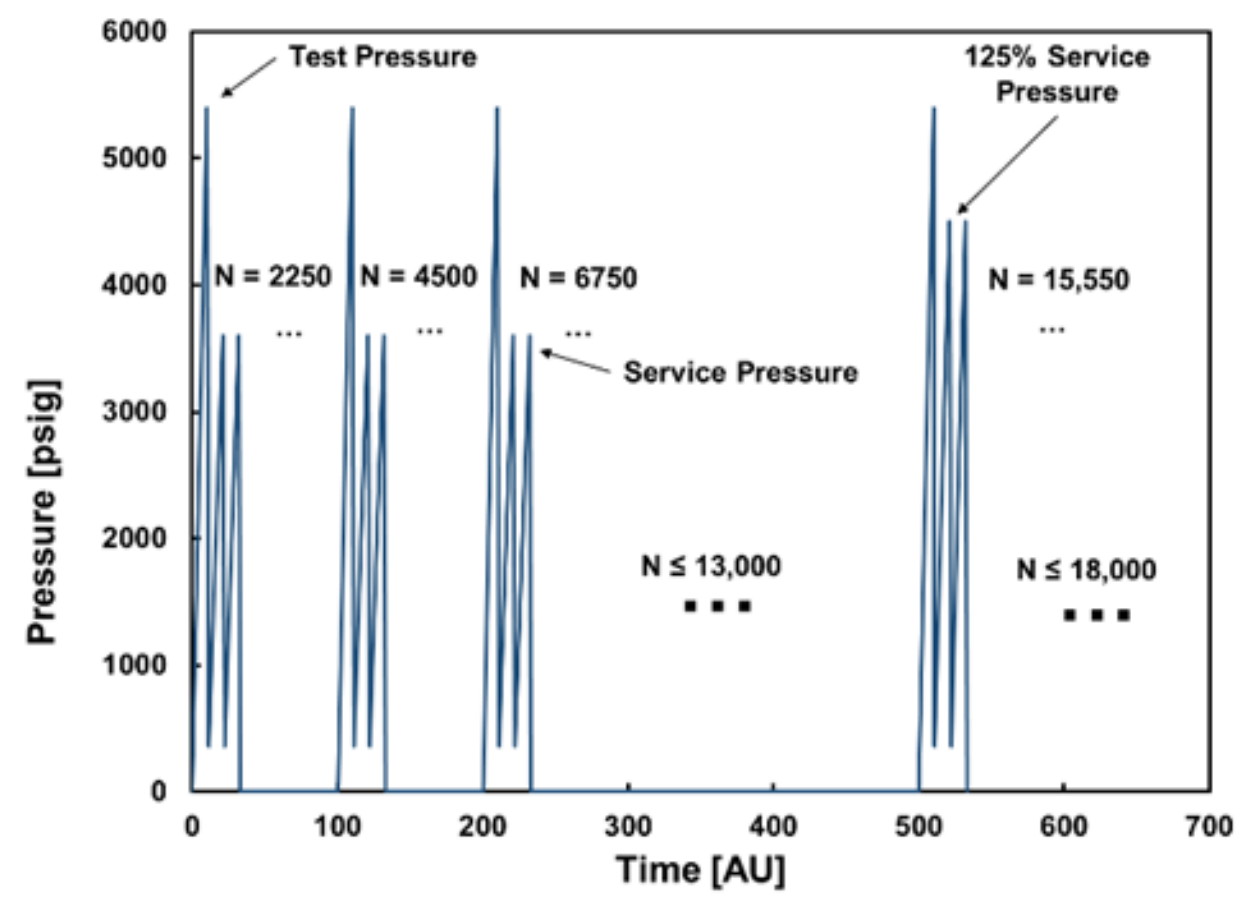

Figure 6. Fatigue test protocol

\subsubsection{Damage Parameter}

In order to monitor the mechanical stiffness during hydraulic fatigue cycle testing and to quantify the total accumulated microstructural damage of the tanks, the subcontractor defined and calculated a damage parameter. Strains from two gauges were attached to each tank, one oriented axially and one oriented in the hoop direction. These measured forces from each strain gage were used to calculate and monitor the damage parameter, $D$, for the tanks:

$$
D=E_{i} / E_{0}
$$

$D=$ damage parameter

$E_{i}=$ the measured modulus from a given channel on the $i^{t h}$ cycle

$E_{0}=$ the measured modulus from a given strain channel on the initial fatigue cycle.

A damage parameter value of one or greater indicated that the tank was not accumulating gross microstructural damage and therefore was not experiencing any degradation of the tank stiffness. A damage parameter value of less than one indicated that the tank was losing mechanical stiffness during the hydraulic fatigue cycle testing and accumulating gross microstructural damage. The damage parameter was further analyzed to determine the damage mechanism and assess the structural durability of the cylinder.

\subsection{Leak Test}

One randomly selected Type III and Type IV tank was subjected to a leak test after hydraulic fatigue cycling according to CGA C-6.4 (CGA 2012). The leak test was conducted to determine if the liner of the tanks had been damaged, which would have resulted in degraded structural 
integrity of the tank. Both tanks passed the leak test according to the acceptance criteria and were not deemed as damaged from additional hydraulic fatigue cycling of the defined 18,000 cycles. 


\section{Test Results}

This section summarizes the results from each of the test procedures conducted on the CNG fuel tanks for EOL characterization.

\subsection{Visual Inspection Results}

All 60 CNG fuel tanks were visually inspected per CGA C-6.2 and CGA C-6.4 if Type III. The visual inspection was conducted on the tanks as they were received, before any testing, as well as a second time following artificial damage and hydraulic fatigue cycling. With the exception of the Type III tanks that experienced the localized impact event at double height, every tank passed the visual inspection, according to the defined criteria, both before and after testing. Table 5 and Table 6 summarize cylinder type, manufacture date, and inspection results for all tanks that were visually inspected.

Table 5. Summary of Visual Inspection Results of Type III CNG Fuel Tanks

\begin{tabular}{|c|c|c|c|c|}
\hline Tank Count & Serial Number & $\begin{array}{l}\text { Manufacture } \\
\text { Date }\end{array}$ & $\begin{array}{l}\text { Internal Visual } \\
\text { Inspection }\end{array}$ & $\begin{array}{l}\text { External Visual } \\
\text { Inspection }\end{array}$ \\
\hline 1 & ALT810N-3324 & Feb. 2002 & PASS & PASS \\
\hline 2 & ALT810N-2188 & Oct. 2001 & PASS & PASS \\
\hline 3 & ALT810N-4105 & April 2002 & PASS & PASS \\
\hline 4 & ALT810N-2562 & Oct. 2001 & PASS & PASS \\
\hline 5 & ALT810N-2191 & Oct. 2001 & FAIL & FAIL \\
\hline 6 & ALT810N-2104 & Oct. 2001 & FAIL & FAIL \\
\hline 7 & ALT810N-3651 & Feb. 2002 & PASS & PASS \\
\hline 8 & ALT810N-3742 & March 2002 & PASS & PASS \\
\hline 9 & ALT810N-1995 & Sept. 2001 & PASS & PASS \\
\hline 10 & ALT810N-2744 & Dec. 2001 & PASS & PASS \\
\hline 11 & ALT810N-3653 & Feb. 2002 & PASS & PASS \\
\hline 12 & ALT810N-2351 & Oct. 2001 & PASS & PASS \\
\hline 13 & ALT810N-3733 & March 2002 & PASS & PASS \\
\hline 14 & ALT810N-2353 & Oct. 2001 & PASS & PASS \\
\hline 15 & ALT810N-2740 & Dec. 2001 & PASS & PASS \\
\hline 16 & ALT810N-2403 & Oct. 2001 & PASS & PASS \\
\hline 17 & ALT810N-3735 & March 2002 & PASS & PASS \\
\hline 18 & ALT810N-3323 & Feb. 2002 & PASS & PASS \\
\hline 19 & ALT810N-2996 & Dec. 2001 & PASS & PASS \\
\hline 20 & ALT810N-3326 & Feb. 2002 & PASS & PASS \\
\hline 21 & ALT810N-2565 & Nov. 2001 & PASS & PASS \\
\hline 22 & ALT810N-3991 & March 2002 & PASS & PASS \\
\hline 23 & ALT810N-3993 & March 2002 & PASS & PASS \\
\hline
\end{tabular}




\begin{tabular}{lllll}
\hline Tank Count & Serial Number & $\begin{array}{c}\text { Manufacture } \\
\text { Date }\end{array}$ & $\begin{array}{c}\text { Internal Visual } \\
\text { Inspection }\end{array}$ & $\begin{array}{c}\text { External Visual } \\
\text { Inspection }\end{array}$ \\
\hline 24 & ALT810N-1976 & Sept. 2001 & PASS & PASS \\
\hline 25 & ALT810N-2099 & Oct. 2001 & PASS & PASS \\
\hline 26 & ALT810N-2107 & Oct. 2001 & PASS & PASS \\
27 & ALT810N-3858 & March 2002 & PASS & PASS \\
\hline 28 & ALT810N-3884 & March 2002 & PASS & PASS \\
\hline 29 & ALT810N-4049 & March 2002 & PASS & PASS \\
\hline 30 & ALT810N-2189 & Oct. 2001 & PASS & PASS \\
\hline
\end{tabular}

Table 6. Summary of Visual Inspection Results of Type IV CNG Fuel Tanks

\begin{tabular}{|c|c|c|c|c|}
\hline Tank Count & Serial Number & $\begin{array}{c}\text { Manufacture } \\
\text { Date }\end{array}$ & $\begin{array}{l}\text { Internal Visual } \\
\text { Inspection }\end{array}$ & $\begin{array}{l}\text { External Visual } \\
\text { Inspection }\end{array}$ \\
\hline 1 & $313-063$ & Aug. 2000 & PASS & PASS \\
\hline 2 & $309-032$ & Aug. 2000 & PASS & PASS \\
\hline 3 & $319-020$ & Aug. 2000 & PASS & PASS \\
\hline 4 & $313-046$ & Oct. 2000 & PASS & PASS \\
\hline 5 & $309-025$ & Aug. 2000 & PASS & PASS \\
\hline 6 & $309-186$ & Sept. 2000 & PASS & PASS \\
\hline 7 & $313-045$ & Oct. 2000 & PASS & PASS \\
\hline 8 & $319-007$ & Oct. 2000 & PASS & PASS \\
\hline 9 & $319-051$ & Oct. 2000 & PASS & PASS \\
\hline 10 & $314-048$ & Aug. 2000 & PASS & PASS \\
\hline 11 & $309-022$ & Aug. 2000 & PASS & PASS \\
\hline 12 & $305-164$ & Aug. 2000 & PASS & PASS \\
\hline 13 & $305-159$ & Aug. 2000 & PASS & PASS \\
\hline 14 & $319-001$ & Oct. 2000 & PASS & PASS \\
\hline 15 & $309-023$ & Aug. 2000 & PASS & PASS \\
\hline 16 & $313-047$ & Sept. 2000 & PASS & PASS \\
\hline 17 & $319-006$ & Oct. 2000 & PASS & PASS \\
\hline 18 & $316-008$ & Oct. 2000 & PASS & PASS \\
\hline 19 & $316-014$ & Oct. 2000 & PASS & PASS \\
\hline 20 & $309-117$ & Aug. 2000 & PASS & PASS \\
\hline 21 & $314-051$ & Oct. 2000 & PASS & PASS \\
\hline 22 & $314-144$ & Oct. 2000 & PASS & PASS \\
\hline 23 & $316-007$ & Oct. 2000 & PASS & PASS \\
\hline 24 & $319-037$ & Oct. 2000 & PASS & PASS \\
\hline
\end{tabular}




\begin{tabular}{lllll}
\hline Tank Count & Serial Number & $\begin{array}{c}\text { Manufacture } \\
\text { Date }\end{array}$ & $\begin{array}{c}\text { Internal Visual } \\
\text { Inspection }\end{array}$ & $\begin{array}{c}\text { External Visual } \\
\text { Inspection }\end{array}$ \\
\hline 25 & $305-163$ & Aug. 2000 & PASS & PASS \\
\hline 26 & $309-181$ & Aug. 2000 & PASS & PASS \\
\hline 27 & $314-050$ & Oct. 2000 & PASS & PASS \\
\hline 28 & $309-026$ & Aug. 2000 & PASS & PASS \\
29 & $305-160$ & Aug. 2000 & PASS & PASS \\
30 & $319-012$ & Oct. 2000 & PASS & PASS \\
\hline
\end{tabular}

\subsection{Modal Acoustic Emission Results}

All 60 CNG fuel tanks were subjected to MAE examination, where the criteria for the MAE acceptance or rejection were defined by ISO Technical Standard 19016 and PHMSA standard "Modal Acoustic Emission Examination Specification for Requalification of Composite Overwrapped Pressure Vessels (cylinders and tubes)" (U.S. DOT 2018) The nondestructive examination was conducted on the tanks as they were received, as well as a second time following artificial damage and hydraulic fatigue cycling.

\subsubsection{Examination of Tanks in Received Condition}

All MAE inspections of as-received tanks passed the examination according to the acceptance criteria. Table 7 and Table 8 summarize cylinder type, manufacture date, and MAE examination results for all tanks.

Table 7. Summary of MAE Examination Results of Type III CNG Fuel Tanks in Received Condition

\begin{tabular}{cccc}
\hline Tank Count & Serial Number & Manufacture Date & MAE Acceptance (Pass/Fail) \\
\hline 1 & ALT810N-3324 & Feb. 2002 & PASS \\
\hline 2 & ALT810N-2188 & Oct. 2001 & PASS \\
\hline 3 & ALT810N-4105 & April 2002 & PASS \\
\hline 4 & ALT810N-2562 & Oct. 2001 & PASS \\
\hline 5 & ALT810N-2191 & Oct. 2001 & PASS \\
\hline 6 & ALT810N-2104 & Oct. 2001 & PASS \\
\hline 7 & ALT810N-3651 & Feb. 2002 & PASS \\
\hline 8 & ALT810N-3742 & March 2002 & PASS \\
\hline 9 & ALT810N-1995 & Sept. 2001 & PASS \\
\hline 10 & ALT810N-2744 & Dec. 2001 & PASS \\
\hline 11 & ALT810N-3653 & Feb. 2002 & PASS \\
\hline 12 & ALT810N-2351 & Oct. 2001 & PASS \\
\hline 13 & ALT810N-3733 & March 2002 & PASS \\
\hline 14 & ALT810N-2353 & Oct. 2001 & PASS \\
\hline 15 & ALT810N-2740 & Dec. 2001 & PASS \\
\hline 16 & ALT810N-2403 & Oct. 2001 & PASS \\
\hline
\end{tabular}




\begin{tabular}{cccc}
\hline Tank Count & Serial Number & Manufacture Date & MAE Acceptance (Pass/Fail) \\
17 & ALT810N-3735 & March 2002 & PASS \\
18 & ALT810N-3323 & Feb. 2002 & PASS \\
19 & ALT810N-2996 & Dec. 2001 & PASS \\
20 & ALT810N-3326 & Feb. 2002 & PASS \\
21 & ALT810N-2565 & Nov. 2001 & PASS \\
22 & ALT810N-3991 & March 2002 & PASS \\
23 & ALT810N-3993 & March 2002 & PASS \\
24 & ALT810N-1976 & Sept. 2001 & PASS \\
25 & ALT810N-2099 & Oct. 2001 & PASS \\
\hline 26 & ALT810N-2107 & Oct. 2001 & PASS \\
27 & ALT810N-3858 & March 2002 & PASS \\
\hline 28 & ALT810N-3884 & March 2002 & PASS \\
\hline 29 & ALT810N-4049 & March 2002 & PASS \\
\hline 30 & ALT810N-2189 & Oct. 2001 & PASS \\
\hline
\end{tabular}

Table 8. Summary of MAE Examination Results of Type IV CNG Fuel Tanks in Received Condition

\begin{tabular}{cccc}
\hline Tank Count & Serial Number & Manufacture Date & MAE Acceptance (Pass/Fail) \\
\hline 1 & $313-063$ & Aug. 2000 & PASS \\
\hline 2 & $309-032$ & Aug. 2000 & PASS \\
\hline 4 & $319-020$ & Aug. 2000 & PASS \\
\hline 5 & $313-046$ & Oct. 2000 & PASS \\
6 & $309-025$ & Aug. 2000 & PASS \\
\hline 7 & $309-186$ & Sep. 2000 & PASS \\
\hline 8 & $313-045$ & Oct. 2000 & PASS \\
\hline 9 & $319-007$ & Oct. 2000 & PASS \\
10 & $319-051$ & Oct. 2000 & PASS \\
11 & $314-048$ & Aug. 2000 & PASS \\
12 & $309-022$ & Aug. 2000 & PASS \\
13 & $305-164$ & Aug. 2000 & PASS \\
14 & $305-159$ & Aug. 2000 & PASS \\
15 & $319-001$ & Oct. 2000 & PASS \\
16 & $309-023$ & Aug. 2000 & PASS \\
17 & $313-047$ & Sep. 2000 & PASS \\
18 & $319-006$ & Oct. 2000 & PASS \\
\hline $316-008$ & Oct. 2000 & PASS \\
\hline
\end{tabular}




\begin{tabular}{cccc}
\hline Tank Count & Serial Number & Manufacture Date & MAE Acceptance (Pass/Fail) \\
\hline 19 & $316-014$ & Oct. 2000 & PASS \\
20 & $309-117$ & Aug. 2000 & PASS \\
21 & $314-051$ & Oct. 2000 & PASS \\
22 & $314-144$ & Oct. 2000 & PASS \\
23 & $316-007$ & Oct. 2000 & PASS \\
24 & $319-037$ & Oct. 2000 & PASS \\
25 & $305-163$ & Aug. 2000 & PASS \\
\hline 26 & $309-181$ & Aug. 2000 & PASS \\
27 & $314-050$ & Oct. 2000 & PASS \\
28 & $309-026$ & Aug. 2000 & PASS \\
29 & $305-160$ & Aug. 2000 & PASS \\
30 & $319-012$ & Oct. 2000 & PASS \\
\hline
\end{tabular}

\subsubsection{Examination of Tanks Following Notch Damage}

After the eight tanks - four Type III and four Type IV-were artificially damaged via notching, they were subjected to MAE examination. None of the eight tanks passed the acceptance criteria and would have been denied for continued use. MAE examination confirmed that a stress concentrator had been introduced into each composite cylinder's microstructure and that the tank's burst strength was degraded as compared to an undamaged cylinder. A summary of the MAE examination results and the identified specific cause of rejection is shown in Table 9.

Table 9. Summary of MAE Results of Tanks Following Notch Damage

\begin{tabular}{llllllll}
\hline $\begin{array}{c}\text { Tank } \\
\text { Count }\end{array}$ & $\begin{array}{c}\text { Design } \\
\text { Type }\end{array}$ & \multicolumn{1}{c}{$\begin{array}{c}\text { Serial } \\
\text { Number }\end{array}$} & $\begin{array}{c}\text { Artificial } \\
\text { Damage Type }\end{array}$ & $\begin{array}{c}\text { Burst } \\
\text { Pressure } \\
\text { (psig) }\end{array}$ & $\begin{array}{c}\text { Burst } \\
\text { Pressure } \\
\text { (Pass/Fail) }\end{array}$ & $\begin{array}{c}\text { MAE } \\
\text { Result } \\
\text { (Pass/Fail) }\end{array}$ & $\begin{array}{c}\text { MAE } \\
\text { Rejection } \\
\text { Cause }\end{array}$ \\
\hline 1 & III & ALT810N-3651 & Notched & 10,510 & Pass & Fail & $\begin{array}{l}\text { BEO, } \\
\text { FTF, FE }\end{array}$ \\
\hline 2 & III & ALT810N-3742 & Notched & 10,655 & Pass & Fail & FE \\
\hline 3 & III & ALT810N-1995 & $\begin{array}{l}\text { Notched }+ \\
\text { Fatigue Cycled }\end{array}$ & 9,830 & Pass & Fail & BEO \\
\hline 4 & III & ALT810N-3651 & $\begin{array}{l}\text { Notched }+ \\
\text { Fatigue Cycled }\end{array}$ & 10,510 & Pass & Fail & BEO, FE \\
\hline 5 & IV & $319-006$ & Notched & 10,000 & Pass & Fail & BEO, FE \\
\hline 6 & IV & $316-008$ & Notched & 9,460 & Pass & Fail & BEO, FE \\
\hline 7 & IV & $316-014$ & $\begin{array}{l}\text { Notched }+ \\
\text { Fatigue Cycled }\end{array}$ & 9,240 & Pass & Fail & BEO, FE \\
\hline 8 & IV & $309-117$ & $\begin{array}{l}\text { Notched }+ \\
\text { Fatigue Cycled }\end{array}$ & 9,220 & Pass & Fail & BEO, FTF \\
\hline BEO & & & & & & \\
\hline
\end{tabular}

BEO: background energy oscillation

FTF: energy greater than the allowable for fiber tow fracture

FE: fretting emission energy violated 


\subsubsection{Examination of Tanks Following Impact Damage}

After the 12 tanks (six Type III and six Type IV) were artificially damaged via impact, they were subjected to MAE examination per in Section A.20 of ISO 11439. MAE evaluation was conducted directly after the impact events, prior to additional fatigue or burst testing. Four Type III tanks passed the MAE examination: two with impact damage inflicted per ISO 11439 and two with localized impact damage as inflicted per the modified procedure with an angled steel iron. Two Type IV tanks passed the MAE examination, both with impact damage inflicted per ISO 11439. MAE examination confirmed that a stress concentrator had been introduced into the six other composite cylinder's microstructure and that the tank's burst strength was degraded as compared to an undamaged cylinder. The four Type III and two Type IV tanks that passed the MAE examination also passed the burst pressurization test. The fatigue and burst tests that followed the MAE examination of the impacted tanks confirmed that the MAE criteria were valid predictors of which tanks experienced degraded structural integrity and ultimately failed the following burst pressure test. A summary of the MAE examination results of the impacted tanks and the identified specific cause of rejection is shown in Table 10.

Table 10. Summary of MAE Results of Tanks Following Impact Damage

\begin{tabular}{|c|c|c|c|c|c|c|c|}
\hline $\begin{array}{l}\text { Tank } \\
\text { Count }\end{array}$ & $\begin{array}{l}\text { Design } \\
\text { Type }\end{array}$ & $\begin{array}{c}\text { Serial } \\
\text { Number }\end{array}$ & $\begin{array}{c}\text { Artificial } \\
\text { Damage Type }\end{array}$ & $\begin{array}{l}\text { Burst } \\
\text { Pressure } \\
\text { (psig) }\end{array}$ & $\begin{array}{c}\text { Burst } \\
\text { Pressure } \\
\text { (Pass/Fail) }\end{array}$ & $\begin{array}{c}\text { MAE } \\
\text { Result } \\
\text { (Pass/Fail) }\end{array}$ & $\begin{array}{c}\text { MAE } \\
\text { Rejection } \\
\text { Cause }\end{array}$ \\
\hline 1 & III & ALT810N-3324 & Impact per ISO 11439 & 11,345 & Pass & Pass & - \\
\hline 2 & III & ALT810N-2188 & $\begin{array}{l}\text { Impact per ISO } 11439 \\
+ \text { Fatigue }\end{array}$ & 10,220 & Pass & Pass & - \\
\hline 3 & III & ALT810N-4105 & Localized Impact & 9,625 & Pass & Pass & - \\
\hline 4 & III & ALT810N-2562 & $\begin{array}{l}\text { Localized Impact + } \\
\text { Fatigue }\end{array}$ & 8,700 & Pass & Pass & - \\
\hline 5 & III & ALT810N-2191 & $\begin{array}{l}\text { Localized Impact at } \\
\text { Double Height }\end{array}$ & 6,110 & Fail & Fail & BEO, FE \\
\hline 6 & III & ALT810N-2104 & $\begin{array}{l}\text { Localized Impact at } \\
\text { Double Height + } \\
\text { Fatigue }\end{array}$ & 7,440 & Fail & Fail & FTF, BEO, FE \\
\hline 7 & IV & $309-022$ & Impact per ISO 11439 & 10,215 & Pass & Pass & - \\
\hline 8 & IV & $305-164$ & $\begin{array}{l}\text { Impact per ISO } 11439 \\
\text { + Fatigue }\end{array}$ & 8,715 & Pass & Pass & - \\
\hline 9 & IV & $305-159$ & Localized Impact & 5,400 & Fail & Fail & FTF, BEO, FE \\
\hline 10 & IV & $319-001$ & $\begin{array}{l}\text { Localized Impact + } \\
\text { Fatigue }\end{array}$ & 5,400 & Fail & Fail & FTF, BEO \\
\hline 11 & IV & $309-023$ & $\begin{array}{l}\text { Localized Impact at } \\
\text { Double Height }\end{array}$ & 6,160 & Fail & Fail & BEO \\
\hline 12 & IV & $313-047$ & $\begin{array}{l}\text { Localized Impact at } \\
\text { Double Height + } \\
\text { Fatigue }\end{array}$ & 7,160 & Fail & Fail & FTF, BEO \\
\hline
\end{tabular}

BEO: background energy oscillation

FTF: energy greater than the allowable for fiber tow fracture

FE: fretting emission energy violated 


\subsection{Burst Pressurization Results of As-Received Tanks}

After visual inspection and MAE examination, 20 tanks - 10 Type III and 10 Type IV-were subjected to hydraulic burst pressurization according to NGV2 to establish a baseline understanding of the tank's structural integrity at the end of its 15 year life in comparison to NGV2 design and performance standard. Burst strength distributions for both tank design types, of all 20 tanks, revealed that each maintained the initial design strength required at time of manufacturing. Table 11 outlines the burst pressure test results of tanks as received from LA Metro Transportation Authority.

Table 11. Summary of Initial Burst Pressure Testing Results

\begin{tabular}{|c|c|c|c|c|c|c|c|}
\hline $\begin{array}{l}\text { Tank } \\
\text { Count }\end{array}$ & $\begin{array}{c}\text { Design } \\
\text { Type }\end{array}$ & $\begin{array}{c}\text { Serial } \\
\text { Number }\end{array}$ & $\begin{array}{l}\text { Manufacture } \\
\text { Date }\end{array}$ & $\begin{array}{c}\text { Visual } \\
\text { Inspection } \\
\text { (Pass/Fail) }\end{array}$ & $\begin{array}{c}\text { MAE } \\
\text { Acceptance } \\
\text { (Pass/Fail) }\end{array}$ & $\begin{array}{c}\text { Burst } \\
\text { Pressure } \\
\text { (Pass/Fail) }\end{array}$ & $\begin{array}{l}\text { Burst } \\
\text { Pressure } \\
\text { (psig) }\end{array}$ \\
\hline 1 & III & ALT810N-2565 & Nov. 2001 & PASS & PASS & PASS & 10,780 \\
\hline 2 & III & ALT810N-3991 & March 2002 & PASS & PASS & PASS & 10,870 \\
\hline 3 & III & ALT810N-3993 & March 2002 & PASS & PASS & PASS & 10,560 \\
\hline 4 & III & ALT810N-1976 & Sept. 2001 & PASS & PASS & PASS & 11,110 \\
\hline 5 & III & ALT810N-2099 & Oct. 2001 & PASS & PASS & PASS & 10,560 \\
\hline 6 & III & ALT810N-2107 & Oct. 2001 & PASS & PASS & PASS & 10,460 \\
\hline 7 & III & ALT810N-3858 & March 2002 & PASS & PASS & PASS & 11,150 \\
\hline 8 & III & ALT810N-3884 & March 2002 & PASS & PASS & PASS & 10,700 \\
\hline 9 & III & ALT810N-4049 & March 2002 & PASS & PASS & PASS & 10,780 \\
\hline 10 & III & ALT810N-2189 & Oct. 2001 & PASS & PASS & PASS & 10,490 \\
\hline 11 & IV & $314-051$ & Oct. 2000 & PASS & PASS & PASS & 10,430 \\
\hline 12 & IV & $314-144$ & Oct. 2000 & PASS & PASS & PASS & 10,690 \\
\hline 13 & IV & $316-007$ & Oct. 2000 & PASS & PASS & PASS & 10,460 \\
\hline 14 & IV & $319-037$ & Oct. 2000 & PASS & PASS & PASS & 10,300 \\
\hline 15 & IV & $305-163$ & Aug. 2000 & PASS & PASS & PASS & 10,070 \\
\hline 16 & IV & $309-181$ & Aug. 2000 & PASS & PASS & PASS & 10,110 \\
\hline 17 & IV & $314-050$ & Oct. 2000 & PASS & PASS & PASS & 10,230 \\
\hline 18 & IV & $309-026$ & Aug. 2000 & PASS & PASS & PASS & 10,050 \\
\hline 19 & IV & $305-160$ & Aug. 2000 & PASS & PASS & PASS & $\mathrm{N} / \mathrm{A}$ \\
\hline 20 & IV & $319-012$ & Oct. 2000 & PASS & PASS & PASS & $\mathrm{N} / \mathrm{A}$ \\
\hline
\end{tabular}

\subsection{Artificially Damaged Tanks Tolerance Results}

This section summarizes the test results of hydraulic fatigue cycling, leak test, and burst pressurization of the 20 tanks subjected to artificial damage via notch and impact events. 


\subsubsection{Hydraulic Fatigue Cycling of Notched Tanks}

Of the four Type III and four Type IV CNG fuel tanks subjected to notch tolerance testing defined in ISO 11439, two of each tank design type were subjected to MAE examination followed by hydraulic fatigue cycle testing for 15,000 cycles per ISO 11439, concluded by EOL burst pressurization test. MAE results successfully detected a stress concentrator that existed in the microstructure of the cylinder after the notch procedure. All four tanks that were hydraulically fatigue cycled did not experience degradation of the tank's stiffness according to the monitored damage parameter of accumulated gross microstructural damage. Table 12 summarizes these results.

Table 12. Hydraulic Fatigue Cycling Test Results of Notched Tanks

\begin{tabular}{cccccc}
\hline $\begin{array}{c}\text { Tank } \\
\text { Count }\end{array}$ & $\begin{array}{c}\text { Design } \\
\text { Type }\end{array}$ & Serial Number & Artificial Damage Type & $\begin{array}{c}\text { Post-Damage } \\
\text { MAE Examination } \\
\text { (Pass/Fail) }\end{array}$ & $\begin{array}{c}\text { 15,000 Fatigue } \\
\text { Cycles } \\
\text { (Pass/Fail) }\end{array}$ \\
\hline 1 & III & ALT810N-1995 & Notched + Fatigue Cycled & PASS & PASS \\
2 & III & ALT810N-2744 & Notched + Fatigue Cycled & PASS & PASS \\
3 & IV & $316-014$ & Notched + Fatigue Cycled & PASS & PASS \\
4 & IV & $309-117$ & Notched + Fatigue Cycled & PASS & PASS \\
\hline
\end{tabular}

The subcontractor estimated that the simulated additional 20 years of service via hydraulic fatigue cycling, when assuming 750 fills per year, reduced the residual burst strength by $7 \%$ of Type III tanks and by $5 \%$ of Type IV tanks when compared to the notched tanks not subjected to additional fatigue cycles. These results suggest that the tanks had additional service life remaining beyond the defined EOL following the artificial damage by notching.

\subsubsection{Burst Pressurization of Notched Tanks}

All eight CNG fuel tanks subjected to notch damage, including the four that were hydraulic fatigue cycled per ISO 11439, underwent EOL burst pressurization as defined in NGV2. All eight tanks met the burst pressure minimum of $8,100 \mathrm{psig}$, the same requirement for CNG fuel tanks at the time of manufacture. These burst pressure test results are summarized in Table 13.

Table 13. Burst Pressure Test Results of Notched Tanks

\begin{tabular}{|c|c|c|c|c|c|c|}
\hline $\begin{array}{l}\text { Tank } \\
\text { Count }\end{array}$ & $\begin{array}{l}\text { Design } \\
\text { Type }\end{array}$ & Serial Number & $\begin{array}{c}\text { Artificial } \\
\text { Damage Type }\end{array}$ & $\begin{array}{c}\text { Post-Notch } \\
\text { MAE } \\
\text { Examination } \\
\text { (Pass/Fail) }\end{array}$ & $\begin{array}{c}\text { Burst } \\
\text { Pressure } \\
\text { (psig) }\end{array}$ & $\begin{array}{c}\text { Burst } \\
\text { Pressure } \\
\text { Met } \\
\text { (Pass/Fail) }\end{array}$ \\
\hline 1 & III & ALT810N-3651 & Notched & PASS & 10,510 & PASS \\
\hline 2 & III & ALT810N-3742 & Notched & PASS & 10,655 & PASS \\
\hline 3 & III & ALT810N-1995 & $\begin{array}{c}\text { Notched + } \\
\text { Fatigue Cycled }\end{array}$ & PASS & 9,830 & PASS \\
\hline 4 & III & ALT810N-2744 & $\begin{array}{c}\text { Notched }+ \\
\text { Fatigue Cycled }\end{array}$ & PASS & 9,860 & PASS \\
\hline 5 & IV & $319-006$ & Notched & PASS & 10,000 & PASS \\
\hline 6 & IV & $316-008$ & Notched & PASS & 9,460 & PASS \\
\hline 7 & IV & $316-014$ & $\begin{array}{l}\text { Notched }+ \\
\text { Fatigue Cycled }\end{array}$ & PASS & 9,240 & PASS \\
\hline 8 & IV & $309-117$ & $\begin{array}{c}\text { Notched + } \\
\text { Fatigue Cycled }\end{array}$ & PASS & 9,220 & PASS \\
\hline
\end{tabular}




\subsubsection{Hydraulic Fatigue Cycling of Impacted Tanks}

Of the 12 tanks subjected to impact damage, two Type III and two Type IV CNG fuel tanks were damaged by impact as defined in ISO 11439. A total of two tanks, one of each design type, were then hydraulically fatigued, followed by the EOL burst pressurization test. Both tanks were subjected to 15,000 cycles as previously defined and did not experience degradation of the tank's stiffness according to the monitored damage parameter of accumulated gross microstructural damage.

Eight of the remaining tanks - four Type III and four Type IV-were subjected to a localized impact event of the cylinder sidewall, a modified impact event to ISO 11439, where two tanks of each design type were then subjected to MAE examination followed by hydraulic fatigue cycle testing for 15,000 cycles to $105 \%$ of service pressure. All four tanks were subjected to 15,000 cycles as previously defined and did not experience degradation of the tank's stiffness according to the monitored damage parameter of accumulated gross microstructural damage. These results suggest that the tanks had additional service life of approximately 20 years remaining beyond the defined EOL following the artificial damage by impact. Table 14 summarizes results of all six tanks that were fatigue-cycled following impact events.

Table 14. Fatigue Cycling Test Results of Impacted Tanks

\begin{tabular}{ccclcc}
\hline $\begin{array}{c}\text { Tank } \\
\text { Count }\end{array}$ & $\begin{array}{c}\text { Design } \\
\text { Type }\end{array}$ & $\begin{array}{c}\text { Serial } \\
\text { Number }\end{array}$ & \multicolumn{1}{c}{$\begin{array}{c}\text { Artificial } \\
\text { Damage Type }\end{array}$} & $\begin{array}{c}\text { Post Fatigue } \\
\text { MAE Result } \\
\text { (Pass/Fail) }\end{array}$ & $\begin{array}{c}\text { 15,000 Fatigue } \\
\text { Cycles } \\
\text { (Pass/Fail) }\end{array}$ \\
\hline 1 & III & ALT810N-2188 & Impact per ISO 11439 + Fatigue & Pass & Pass \\
2 & III & ALT810N-2562 & Localized Impact + Fatigue & Pass & Pass \\
3 & III & ALT810N-2104 & $\begin{array}{l}\text { Localized Impact at Double } \\
\text { Height + Fatigue }\end{array}$ & Fail & Pass \\
4 & IV & $305-164$ & $\begin{array}{l}\text { Impact per ISO 11439 + Fatigue } \\
\text { Localized Impact + Fatigue }\end{array}$ & Pass & Pass \\
5 & IV & $319-001$ & Fail & Pass \\
6 & IV & $313-047$ & $\begin{array}{l}\text { Localized Impact at Double } \\
\text { Height + Fatigue }\end{array}$ & Fail & Pass \\
\hline
\end{tabular}

\subsubsection{Burst Pressurization of Impacted Tanks}

Of the 12 tanks subjected to impact damage, two Type III and two Type IV CNG fuel tanks were subjected to impact damage as defined in ISO 11439, followed by the EOL burst pressurization test. All four tanks met the minimum required burst strength according to the acceptance criteria defined in NGV2 of 8,100 psig.

The remaining eight tanks, four Type III and four Type IV were subjected to a modified localized impact event on the cylinder sidewall. Two tanks of each design type from this sample of eight were then subjected to MAE examination, followed by hydraulic fatigue cycle testing and burst pressurization. The remaining four tanks were only exposed to burst pressurization after the impact events.

The visual inspection of the tanks following the impact events revealed that only the two Type III cylinders subjected to the highest energy impact event exhibited visual indications, and did not meet the acceptance criteria. The other four Type III cylinders did not exhibit any visual indications. Of further significance, none of the six Type IV cylinders had visual damage that did 
not meet acceptance criteria, even though the burst strength had been significantly compromised in some instances.

The four tanks - two Type III and two Type IV-subjected to the standard impact event defined in ISO 11439 passed the minimum required burst pressure of 8,100 psig after being damaged and/or fatigue cycled. The two Type III tanks subjected to the modified procedure of localized impact events also met the minimum required burst pressure after damage and/or fatigue cycling. However, the two Type IV tanks subjected to the modified procedure of localized impact events did not meet the minimum burst strength requirement of 8,100 psig. All four tanks - two Type III and two Type IV tanks - subjected to the modified procedure with a doubled drop height failed to meet the minimum required burst strength. Therefore, the higher energy impact from local impact events drastically reduced the burst strength performance of both design types of cylinders, especially Type IV. Table 15 summarizes results of all 12 tanks that were pressurized until burst following impact events and fatigue cycling.

Table 15. Burst Pressure Test Results of Impacted Tanks

\begin{tabular}{|c|c|c|c|c|c|c|c|}
\hline $\begin{array}{l}\text { Tank } \\
\text { Count }\end{array}$ & $\begin{array}{l}\text { Design } \\
\text { Type }\end{array}$ & $\begin{array}{l}\text { Serial } \\
\text { Number }\end{array}$ & $\begin{array}{c}\text { Artificial } \\
\text { Damage Type }\end{array}$ & $\begin{array}{c}\text { Burst } \\
\text { Pressure } \\
\text { (psig) }\end{array}$ & $\begin{array}{c}\text { Burst } \\
\text { Pressure } \\
\text { (Pass/Fail) }\end{array}$ & $\begin{array}{c}\text { MAE } \\
\text { Result } \\
\text { (Pass/Fail) }\end{array}$ & $\begin{array}{c}\text { MAE } \\
\text { Rejection } \\
\text { Cause } \\
\end{array}$ \\
\hline 1 & III & ALT810N-3324 & $\begin{array}{l}\text { Impact per ISO } \\
11439\end{array}$ & 11,345 & Pass & Pass & - \\
\hline 2 & III & ALT810N-2188 & $\begin{array}{l}\text { Impact per ISO } \\
11439+\text { Fatigue }\end{array}$ & 10,220 & Pass & Pass & - \\
\hline 3 & III & ALT810N-4105 & Localized Impact & 9,625 & Pass & Pass & - \\
\hline 4 & III & ALT810N-2562 & $\begin{array}{l}\text { Localized Impact } \\
\text { + Fatigue }\end{array}$ & 8,700 & Pass & Pass & - \\
\hline 5 & III & ALT810N-2191 & $\begin{array}{l}\text { Localized Impact } \\
\text { at Double Height }\end{array}$ & 6,110 & Fail & Fail & $\mathrm{BEO}, \mathrm{FE}$ \\
\hline 6 & III & ALT810N-2104 & $\begin{array}{l}\text { Localized Impact } \\
\text { at Double Height } \\
+ \text { Fatigue }\end{array}$ & 7,440 & Fail & Fail & $\begin{array}{l}\text { FTF, } \\
\text { BEO, FE }\end{array}$ \\
\hline 7 & IV & $309-022$ & $\begin{array}{l}\text { Impact per ISO } \\
11439\end{array}$ & 10,215 & Pass & Pass & - \\
\hline 8 & IV & $305-164$ & $\begin{array}{l}\text { Impact per ISO } \\
11439 \text { + Fatigue }\end{array}$ & 8,715 & Pass & Pass & - \\
\hline 9 & IV & $305-159$ & Localized Impact & 5,400 & Fail & Fail & $\begin{array}{c}\text { FTF, } \\
\text { BEO, FE }\end{array}$ \\
\hline 10 & IV & $319-001$ & $\begin{array}{l}\text { Localized Impact } \\
+ \text { Fatigue }\end{array}$ & 5,400 & Fail & Fail & FTF, BEO \\
\hline 11 & IV & $309-023$ & $\begin{array}{l}\text { Localized Impact } \\
\text { at Double Height }\end{array}$ & 6,160 & Fail & Fail & BEO \\
\hline 12 & IV & $313-047$ & $\begin{array}{l}\text { Localized Impact } \\
\text { at Double Height } \\
+ \text { Fatigue }\end{array}$ & 7,160 & Fail & Fail & FTF, BEO \\
\hline
\end{tabular}

BEO: background energy oscillation

FTF: energy greater than the allowable for fiber tow fracture

FE: fretting emission energy violated

\subsection{Hydraulic Fatigue Cycling Results}

Of the 20 tanks subjected to hydraulic fatigue cycling per FMVSS No. 304, all 20 successfully completed the additional 18,000 cycles simulating 20 years of continued service. Two of these 
20 tanks that were hydraulically fatigued were also leak-tested according to NGV2. Each of the 20 tanks was then subjected to a burst pressurization test, where they all exceeded the minimum burst pressure requirement of $8,100 \mathrm{psig}$. Table 16 summarizes the tests conducted on the tanks that were hydraulically fatigued.

Table 16. Results of Tanks Hydraulically Fatigued Without Additional Damage

\begin{tabular}{|c|c|c|c|c|c|c|}
\hline $\begin{array}{l}\text { Tank } \\
\text { Count }\end{array}$ & $\begin{array}{l}\text { Design } \\
\text { Type }\end{array}$ & Serial Number & $\begin{array}{c}\text { Manufacture } \\
\text { Date }\end{array}$ & $\begin{array}{c}\text { Hydraulic } \\
\text { Fatigued (cycles) }\end{array}$ & $\begin{array}{c}\text { Burst Pressure } \\
\text { (psig) }\end{array}$ & $\begin{array}{c}\text { Burst } \\
\text { Pressure Met } \\
\text { (Pass/Fail) }\end{array}$ \\
\hline 1 & III & ALT810N-3653 & Feb. 2002 & 15,000 & 10,720 & PASS \\
\hline 2 & III & ALT810N-2351 & Oct. 2001 & 15,000 & LEAK TESTED & NA \\
\hline 3 & III & ALT810N-3733 & March 2002 & 15,000 & 10,800 & PASS \\
\hline 4 & III & ALT810N-2353 & Oct. 2001 & 15,000 & 10,120 & PASS \\
\hline 5 & III & ALT810N-2740 & Dec. 2001 & 15,000 & 10,620 & PASS \\
\hline 6 & III & ALT810N-3735 & March 2002 & 15,000 & 10,380 & PASS \\
\hline 7 & III & ALT810N-3323 & Feb. 2002 & 15,000 & 11,010 & PASS \\
\hline 8 & III & ALT810N-2996 & Dec. 2001 & 15,000 & 11,130 & PASS \\
\hline 9 & III & ALT810N-3326 & Feb. 2002 & 15,000 & 11,150 & PASS \\
\hline 10 & III & ALT810N-2403 & Oct. 2001 & 15,000 & 10,610 & PASS \\
\hline 11 & IV & $313-063$ & Oct. 2000 & 15,000 & 9,750 & PASS \\
\hline 12 & IV & $309-032$ & Aug. 2000 & 15,000 & 9,830 & PASS \\
\hline 13 & IV & $319-020$ & Oct. 2000 & 15,000 & 10,150 & PASS \\
\hline 14 & IV & $313-046$ & Sept. 2000 & 15,000 & 10,100 & PASS \\
\hline 15 & IV & $309-025$ & Aug. 2000 & 15,000 & 10,360 & PASS \\
\hline 16 & IV & $309-186$ & Aug. 2000 & 15,000 & 10,100 & PASS \\
\hline 17 & IV & $313-045$ & Sept. 2000 & 15,000 & LEAK TESTED & NA \\
\hline 18 & IV & $319-007$ & Oct. 2000 & 15,000 & 10,070 & PASS \\
\hline 19 & IV & $319-051$ & Oct. 2000 & 15,000 & 10,740 & PASS \\
\hline 20 & IV & $314-048$ & Oct. 2000 & 15,000 & $9,310^{\mathrm{a}}$ & PASS \\
\hline
\end{tabular}

${ }^{a}$ The burst pressure for S/N 314-048 was not considered valid for distribution determination due to a mechanical pump failure resulting in a mixed mode burst/static fatigue failure as the cause of failure.

\subsection{Leak Test}

Both tanks, one Type III and one Type IV, did not display any signs of leak according to CGA C-6.4 and passed the test according to the defined criteria after being fatigue cycled according to FMVSS No. 304.

Table 17. Summary of Leak Test Results

\begin{tabular}{llllll}
\hline $\begin{array}{l}\text { Tank } \\
\text { Count }\end{array}$ & $\begin{array}{l}\text { Tank } \\
\text { Type }\end{array}$ & Serial Number & $\begin{array}{c}\text { Manufacture } \\
\text { Date }\end{array}$ & $\begin{array}{c}\text { Hydraulic Fatigue } \\
\text { (cycles) }\end{array}$ & $\begin{array}{c}\text { Visual } \\
\text { Inspection }\end{array}$ \\
\hline 1 & III & ALT810N-2351 & Oct. 2001 & 18,000 & PASS \\
2 & IV & $314-045$ & Sept. 2000 & 18,000 & PASS \\
\hline
\end{tabular}

Each tank met the acceptance criteria defined in CGA C- 6.4 confirming that the additional simulated service life from 18,000 cycles did not cause degradation of the tank resulting in a leak failure mode. 


\section{Conclusion}

All 60 CNG fuel tanks that were visually inspected once received from the LA Metro Transportation Authority passed per CGA C-6.2 and CGA C-6.4. They also passed the MAE examination according to ISO Technical Standard 19016 and PHMSA standard "Modal Acoustic Emission Examination Specification for Requalification of Composite Overwrapped Pressure Vessels (cylinders and tubes)." The 60 tanks were all beyond their defined useful life of 15 years but seemed to be structurally sound based on the results of the initial visual inspection and MAE examination.

The 20 tanks - 10 Type III and 10 Type IV—subjected to hydraulic burst pressurization to establish a baseline understanding of the tank's structural integrity at the end of their 15 year life according to NGV2 design and performance standard all exceeded the minimum burst strength requirement. These results indicate that the tanks maintained the required strength for burst pressurization at the time of manufacture and did not experience any significant strength degradation during their use in service.

Visual inspections did not effectively identify tanks with compromised structural integrity. Ten of the 12 tanks subjected to artificial damage passed visual inspection; the remaining two tanks subjected to artificial damage by notching did not. Both tanks that failed were Type III cylinders. The remaining tanks did not exhibit any rejectable visual indications, although 4 of the 10 tanks' structural integrity was compromised and later failed to meet the burst pressurization requirement.

MAE examination successfully detected the compromised structural integrity of all eight tanks subjected to artificial damage by notch events. Four Type III tanks and two Type IV tanks, of the 12 total tanks subjected to artificial damage by impact events, passed the MAE examination after the impact events. MAE examination confirmed that a stress concentrator had been introduced into the six other composite cylinders' microstructure and that the tanks' structural integrity had been compromised and would not meet minimum burst pressurization requirements. The four Type III and two Type IV tanks that passed the MAE examination also passed the burst pressurization test, and therefore did not have damage that affected the tank's structural integrity. Although not all of the artificial damage events resulted in failure modes of the CNG fuel tanks, those that did have compromised structural integrity were accurately predicted by MAE examination.

Of the 20 tanks subjected to hydraulic fatigue cycling as defined in FMVSS No. 304, all 20 successfully completed the additional 18,000 cycles that simulated 24 years of continued service when assuming 750 fills per year. Two of the tanks that were hydraulically fatigued also passed the leak test according to NGV2, showing no degradation that resulted in a leak failure mode after the additional service. Each of the 20 tanks then exceeded the minimum burst pressurization requirement for tanks at the time of manufacture. The results of burst pressurization following hydraulic fatigue cycling of the tanks that were not subjected to latent damage suggest the potential of additional service life for CNG tanks beyond their defined EOL.

The potential opportunity of continued use of CNG tanks that have not been subjected to potential physical damage could be supported by additional research and development. An 
expanded CNG fuel tank sample size to characterize tank integrity after experiencing a full service life in a variety of applications could further verify such potential. Visual inspection was not sufficient in identifying damage inflicted by a localized impact test on Type III and Type IV CNG fuel tanks, whereas a nondestructive evaluation method of MAE successfully assessed the structural integrity of the tanks. MAE examination does not require that tanks be removed from the vehicle assembly and could potentially validate tank integrity beyond visual inspection. 


\section{References}

Alternative Fuels Data Center (AFDC). 2020. "Natural Gas Vehicles.” Washington, D.C.: U.S. Department of Energy Office of Energy Efficiency and Renewable Energy. http://www.afdc.energy.gov/vehicles/natural_gas.html.

Compressed Gas Association (CGA). 2012. CGA - C-6.4: Methods for External Visual Inspection of Natural Gas Vehicle (NGV) and Hydrogen Gas Vehicle (HGV) Fuel Containers and Their Installations. Chantilly, VA: Compressed Gas Association.

Compressed Gas Association (CGA). 2013. CGA - C-6.2: Standard for Visual Inspection and Requalification of Fiber Reinforced High Pressure Cylinders. Chantilly, VA: Compressed Gas Association.

CSA Group/American National Standards Institute (CSA/ANSI). 2019. CSA/ANSI NGV 2-2019: Compressed Natural Gas Vehicle Fuel Containers. Washington, D.C.: American National Standards Institute.

Electronic Code of Federal Regulations (e-CFR). 2020. “\$571.304 Standard No. 304; Compressed natural gas fuel container integrity." Washington, D.C.: U.S. Government Publishing Office. https://www.ecfr.gov/cgi-bin/text$\underline{\mathrm{idx}}$ ?SID=f1 ee7a92fdcf1b56dcf718204a16a96f\&mc=true\&node=se49.6.571 $1304 \& \mathrm{rgn}=\operatorname{div} 8$

International Organization for Standardization (ISO). 2000. ISO 11439:2000: Gas cylindersHigh pressure cylinders for the on-board storage of natural gas as a fuel for automotive vehicles. Geneva, Switzerland: ISO.

U.S. Department of Transportation (U.S. DOT). 2018. Modal acoustic emission (MAE) Examination Specification for Requalification of Composite Overwrapped Pressure Vessels (cylinders and tubes). Washington, D.C.: U.S. Department of Transportation Pipeline and Hazardous Materials Safety Administration. https://www.phmsa.dot.gov/technicalresources/hazmat-technical-resources/modal-acoustic-emission-mae-examination-specificationfor-requalification-of-composite-overwrapped-pressure-vessels-cylinders-and-tubes. 